\title{
Thermal building upgrade with off-grid PV system: a Polish case
}

\author{
Sylwia Wciślik (D) Dagmara Kotrys-Działak
}

Received: 30 March 2021 / Accepted: 11 July 2021 / Published online: 6 September 2021

(C) The Author(s) 2021

\begin{abstract}
Nowadays, one of the basic requirements for thermally upgraded buildings involves limitation in $\mathrm{CO}_{2}$ emission even by over $90 \%$. To fulfil these criteria, it is necessary to use alternative energy sources and photovoltaics constitutes a reasonable option for this. This paper addresses an analysis of the efficiency and profitability of a photovoltaic system located in the geometric center of Europe-Poland, where the intensity of solar irradiation is not very high compared to other European countries. The difference of total solar radiation density between Poland and Malta is $49.2 \%$, from analysis based on SolarGIS base. The PV Lighthouse calculator was used for global power density and photon current examination for a Polish city and locations of the highest and the lowest solar radiation values, Malta and Finland, respectively. This case study concerns a thermally upgraded building; a gas boiler was replaced by a heat pump supported by an off-grid PV system. To achieve a reduction in $\mathrm{CO}_{2}$ emission of $90 \%$, it is necessary to install $182 \mathrm{PV}$ cells, which generates high investment costs. An investment is entirely profitable with $70 \%$ of funding with Simple Pay Back Time, SPBT $\sim 7$ years although Net Present Value, NPV $>0$; Internal Rate of Return, IRR $=10.6 \%$.
\end{abstract}

S. Wciślik $(\bowtie) \cdot D$. Kotrys-Działak

Department of Piped Utility Systems, Faculty of Environmental, Geomatic and Energy Engineering, Kielce University of Technology, Aleja Tysiaclecia Panstwa Polskiego 7,

25-314 Kielce, Poland

e-mail: sylwiazw@tu.kielce.pl

D. Kotrys-Działak

e-mail: ddzialak@tu.kielce.pl
Keywords Environmental efficiency · Heat pump · Offgrid PV system · Modernization · Economic analysis . Ecological effect

\section{Introduction}

When searching for efficient techniques increasing the energy potential related to the conversion of pure energy originating from the Sun (Kabir et al. 2018) — a spectral type $\mathrm{G}$ star, attempts are made to utilise it both by means of direct-helioelectric, as well as indirect methods, related to heat transfer (Orzechowski and Stokowiec 2016), meaning heliothermal. Thus, the commissioning of installations with photovoltaic cells with increasingly larger areas and higher powers seems to be a reasonable trend (Renewable Energy Institute 2020). Such an action also follows one of the main objectives of the amended EU directive related to the energy characteristics of buildings (Directive (EU) 2018), meaning the reduction of the emission of greenhouse gases until 2050 by $80-95 \%$ compared to 1990 . In the long term, it will enable conversion of existing buildings into buildings with an almost zero energy consumptionfor which the ratio of demand for non-renewable primary energy $\mathrm{PE}$ is close to $0 \mathrm{kWh} /\left(\mathrm{m}^{2}\right.$ year $)$. A solution to this involves an increase in the scale of complex and deep thermal upgrading, as well as the construction of new facilities with a low emission of $\mathrm{CO}_{2}$ and particulate matter (PM).

The term-deep thermal upgrading is to be understood as reaching such an energy standard of a building 
after thermal upgrading, which would fulfil requirements related to energy efficiency (Rasmussen 2017) like those for new buildings, and, e.g. this standard for residential single-family and multi-family buildings expressed by the ratio of demand for nonrenewable primary energy for the needs of heating, ventilation and the preparation of warm utility water amounts to $\mathrm{PE} E_{\max , \mathrm{H}+\mathrm{w}}=70$ and $65 \mathrm{kWh} /\left(\mathrm{m}^{2}\right.$ year $)$, respectively; educational buildings: $\mathrm{PE}_{\max , \mathrm{H}+\mathrm{w}}=190$ $\mathrm{kWh} /\left(\mathrm{m}^{2}\right.$ year) (status for Poland - the geometric centre of Europe - as of 1 January 2021). The remaining member states with a longer membership in the European Union are under an obligation to make the energy standards of buildings erected starting from 2021 similar to those of zero-energy buildings.

Poland should have implemented the provisions of Directive (Directive (EU) 2018) by 10 March 2020. Meanwhile, only $1 \%$ of single-family buildings in Poland are energy efficient, meaning that the ratio of demand for non-renewable primary energy $\mathrm{PE}_{\max }=95$ $\mathrm{kWh} / \mathrm{m}^{2}$ year (starting from $2021, \mathrm{PE}_{\max }=70 \mathrm{kWh} / \mathrm{m}^{2}$ year), and almost $70 \%$ are heated using black coal and require modernisation.

European law (Renewable Energy Institute 2020; Directive (EU) 2018; Directive 2006, 2009) encourages the use of renewable energy sources. However, sure solutions seem to be unprofitable. Efficiency of some renewable energy sources usage, e.g. PV systems strongly depends on i.e. climate conditions but, on a way of electrical network connection (on-grid, off-grid, tracking) and on economic situation of specific country. Due to this, there is an observed increase in the number of submitted applications for the funding of actions related to thermal upgrading, the assembly of RES installations and the auditing of energy and energy efficiency.

Belgium is among the countries that saw a considerable increase in powers resulting from the installed PV cells (Huijben et al. 2016) during the last 5 years.

A review of government measures which influenced both the exponential increase in new PV systems, as well as their stagnation between 2006 and 2013, is discussed in (Directive 2009).

The report (Renewable Energy Institute 2020) also indicates that the combined power installed in photovoltaic sources in Poland amounted to approx. $1500 \mathrm{MW}$ as by the end of 2019 (three times more than in 2018), while in May of 2020 it exceeded 1950 MW (an increase by almost $30 \%$ was recorded compared to 2019).
In 2019, Poland was rated fifth among EU countries, due to a yearly power increase of $0.9 \mathrm{GW}$ (i.e. almost $40 \%$ of annual growth). It is predicted that in mid-2020 Poland will be rated 4th among EU countries in terms of new installed power. (Renewable Energy Institute 2020) predicts that even $1 \mathrm{GW}$ of new PV installations will be added in the whole year of 2020, and the total power of photovoltaic installations in Poland at the end of 2020 will amount to $2.5 \mathrm{GW}$.

Among European countries, the highest increase in new PV power in 2018 was recorded in Germany (over $3 \mathrm{GW})$, the Netherlands ( $1.5 \mathrm{GW})$, France $(1.3 \mathrm{GW})$ and Hungary (over $0.5 \mathrm{GW}$ ); these are followed by Italy, Spain, Greece and Czechia (Jäger-Waldau et al. 2019). Although RES directive (Directive 2009) was introduced already in 2009, small incremental PV increases were present during first 6 years and only in 2018 significant increase in dynamic installation and power originating from PV in Europe was observed (more than 50\% increase from 2017 (Jäger-Waldau et al. 2019)).

An analysis of the operation of over $31,000 \mathrm{PV}$ systems installed in Europe between 2006 and 2014 indicates that it is difficult to determine their capacity unambiguously (Leloux et al. 2015) due to the significant difference in the efficiency of the inverters and modules, as well as the technology of their production. There are estimates of an even $30 \%$ difference in the efficiency of any system, resulting from the quality of production of the modules themselves.

In order to assess the capacity of a PV system, the socalled PR ratio is determined, which measures the difference between the real and theoretical production of energy by a photovoltaic system, expressed as percentage of energy generated by a system relative to potential energy calculated by measuring the intensity of solar irradiation and temperature (Gaglia et al. 2017). Over seven years, the recorded improvement in the annual increase in the PR ratio amounted to approximately $0.5 \%$. The desired unit performance ratio PR for new installations is 0.84 . When reached, such a value would influence an improvement in the capacity of PV systems by approximately $10 \%$ and the same level of reduction in the cost of consumption of electricity (Leloux et al. 2015).

For a quick assessment of the ability to use the energy of solar irradiation for a given region in the world, country or town, it is possible to implement physical and mathematical models used to perform simulations of the efficiency of solar cells into the computer 
environment. In here, attention should be paid to the fact that solar irradiation which reaches the surface of an absorber located on the ground is weakened by Earth's atmosphere and other phenomena, such as scattering, reflection or attenuation (typical anisotropic solar radiation model is widely discussed and accessed in literature (Seidel et al. 2010)).

Relatively fast, simple and most popular radiative transfer models (RTMs), taking into account, e.g. atmospheric transmission vs wavelength, Rayleigh scattering, aerosol scattering, water vapour absorption, ozone absorption, unmixed gas absorption, turbidity, precipitable water vapour, Earth-Sun factor, include: the Simple Model of the Atmospheric Radiative Transfer of Sunshine (SMART) with an uncertainty range of up to $5 \div 10 \%$ (Seidel et al. 2010) and the Model of American Society for Testing and Materials (ASTM). Moreover, the following models are also known: Second Simulation of a Satellite Signal in the Solar Spectrum (6S) (Vermote et al. 1997), SCIATRAN (Rozanov et al. 2005), SHARM (Muldashev et al. 1999), RT3 (Evans and Stephens 1991), RTMOM (Govaerts 2006), RAY (Zege and Chaikovskaya 1996), STAR (Ruggaber et al. 1994), Pstar2 (Ota et al. 2010), DISORT (Stamnes et al. 1988), along with computer programs use them -: MODTRAN (Berk et al. 1987), STREAMER (Key and Schweiger 1998) and SBDART (Ricchiazzi et al. 1998), PV Lighthouse, SMART (Mehta 2014), SOLAR GIS, Solar CalQ 1.0 and others.

Currently, one of the basic requirements faced by buildings undergoing modernisation involves limitation in the emission of carbon dioxide even by over $90 \%$ compared to original values. In order to fulfil these criteria, it is necessary to use alternative solutions based on renewable energy sources. In here, photovoltaics constitutes a reasonable option and provides the possibility to achieve a high level of reduction in the emission of primary contaminants, such as $\mathrm{CO}_{2}, \mathrm{SO}_{\mathrm{x}}, \mathrm{NO}_{\mathrm{x}}$ or solid particles.

To achieve European climate goals and in order to motivate to increase the share of RES (in this case energy from PV) in the total energy balance in countries with low energy prices it is proposed in (Radl et al. 2020) to design and set grid charges in accordance with the 'polluter pays' principle. Moreover, financial support as well as the obligation of photovoltaic installations would seem to be the most reasonable solution.

In (Radl et al. 2020) it is also discussed the impact of grid fees, irradiance and local consumption on the profitability of PV electricity on the basis of eight European Countries with different specific conditions. As it turns out, in countries with high number of sun hours (e.g. Spain, Portugal, Italy), high-power PV systems are profitable without any subsidies or government programs. It is also worth emphasizing that among the analysed countries, the investments into Battery Energy Storage Systems - BESS are only beneficial in Spain and Portugal. On the way, on the basis of (Jäger-Waldau 2019), it is stated that tracking off-grid and consumer product markets is extremely complicated.

In some cases, an analysis of the profitability of PV systems utilisation indicates the lack of feasibility. These may include, i.e.: resource potential (location and landform), technical potential (i.e. way of electrical grid connection) and economic potential (actual economical politics, technology costs and so on). As it turns out, there is no universal indicator for assessing the economic situation of a given country in the context of obtaining solar energy from photovoltaic cells (Bódis et al. 2019). In this case, the most common expression is Levelized Cost of Electricity (or Energy), LCOE (Vartiainen et al. 2015). This indicator can be calculated using the Eq. (1) and it is the quotient of the net present value of all costs incurred in the total lifetime of a given installation to the total amount of electricity generated by it. This seems to be the way to discuss the installed capacity and economic potential of PV cells (but also other renewable energy sources) in different European countries.

$$
\begin{aligned}
\mathrm{LCOE} & =\frac{\text { all costs incurred in the total lifetime of a given installation }}{\text { the total amount of electricity generated }} \\
& =\frac{\sum_{\mathrm{t}=1}^{\mathrm{n}} \frac{\mathrm{I}_{\mathrm{t}}+\mathrm{M}_{\mathrm{t}}+\mathrm{F}_{\mathrm{t}}}{(1+\mathrm{R})^{\mathrm{t}}}}{\sum_{\mathrm{t}=1}^{\mathrm{n}} \frac{\mathrm{E}_{\mathrm{t}}}{(1+\mathrm{R})^{\mathrm{t}}}}
\end{aligned}
$$

where: $\mathrm{I}_{\mathrm{t}}$-investment expenditures in the year $\mathrm{t}, \mathrm{M}_{\mathrm{t}}-$ operations and maintenance expenditures in the year $t$, $\mathrm{F}_{\mathrm{t}}$-fuel expenditures in the year $\mathrm{t}$, which is zero for PV electricity, $\mathrm{E}_{\mathrm{t}}$ - electrical energy generated in the year $\mathrm{t}$, $\mathrm{R}$ - discount rate, $\mathrm{n}$ - expected lifetime of system or power station.

Due to technological progress, research activities and European market development, a drastic decrease in the prices of assembly, cells and PV installations has been observed. However, the profitability of an investment is usually determined at the design stage. Assuming in this case no fuel costs $\left(F_{t}=0\right)$, the Weighted Average Cost 
of Capital, WACC (see Eq. 2) adversely affects the LCOE value.

$\mathrm{WACC}=\frac{\mathrm{E}}{\mathrm{E}+\mathrm{D}} \cdot \mathrm{R}_{\mathrm{e}}+\frac{\mathrm{D}}{\mathrm{E}+\mathrm{D}} \cdot \mathrm{R}_{\mathrm{d}}\left(1-\mathrm{T}_{\mathrm{c}}\right)$,

where E-market value of the company's equity, $\mathrm{D}$-market value of the company's debt, $\mathrm{R}_{\mathrm{e}}$ - equity cost, $R_{d}$ - debt cost, $T_{c}$ - corporate tax rate, E/(E+ D) - equity (percentage of financing), $\mathrm{D} /(\mathrm{E}+\mathrm{D})$ - debt (percentage of financing).

The combination of high debt and low cost of debt in some countries outside the EU allowed the signing of beneficial PPAs (Power Purchase Agreements) (JägerWaldau 2019).

When analysing the impact of financing on LOCE, it was found that with WACC $=12 \%$, the financing costs would have amount to $50 \%$ of the total LOCE value. Hence, the cost of producing PV energy is increasingly dependent on an environment with low financial risk and costs, rather than on high levels of solar irradiation (Jäger-Waldau 2019).

Most of the considerations related to LCOE determination assume a certain level of the capital cost of financing the investment (Lazard 2016). In fact, the cost of capital is a variable value that depends on several market factors. Changing certain factors of the capital cost can lead to major changes in the LCOE of a given energy project (Dzieża 2017).

In (Bódis et al. 2019), a method of assessing the technical potential of electricity production from PV cells mounted on the roofs in the EU countries was developed. For this purpose, up-to-date spatial information (with a resolution of $100 \mathrm{~m}$ ) on the building stock in the EU and the Photovoltaic Geographical Information System (PVGIS) methodology were used. It turned out that roofs across the EU could cover around $24 \%$ of the annual electricity demand (i.e. $680 \mathrm{TWh}$ ). The inference was made on the basis of the average cost of electricity (LCOE) and country-specific parameters (taking into account, e.g. energy prices). An interesting point of the paper is the presentation of the influence of the WACC value on spatial distribution of the LCOE for rooftop solar PV installations. It follows that the most favourable LOCE values are assigned to countries with the highest solar energy potential (e.g. Cyprus EUR 6.19 EURcent/kWh, Malta 7 EURcent/kWh), and the lowest correspond to less sunny locations (e.g. northern
Finland areas). As the Weighted Average Cost of Capital turns out, WACC does not always correlate with LOCE values. The countries with good insolation conditions, but high capital costs (e.g. Bulgaria, Croatia) have a lower technical and economic solar electricity potential than countries with lower production costs, such as Germany, Belgium. It was also noted that at present it is not possible to achieve grid parity for the countries of Eastern Europe, which include, e.g. Poland, Romania, Hungary, Czech Republic, Slovakia, Croatia, Lithuania, Latvia, Estonia.

However, the LOCE parameter exposes some limitations (Radl et al. 2020); including profile cost (flexibility and utilization effects), balancing costs and grid costs; and should be contained in all LCOE costs of the electricity generation technology. Moreover, (Dzieża 2017) describes in great details other critical measures of LCOE as an indicator of making investment decisions in the energy sector. These include:

- failure to take into account the flexibility of energy projects and project risks,

- no distinction between marginal costs and capital expenditure.

In (Campisi et al. 2018) an interesting and more and more popular model of Multi Criteria Decision Making, MCDM, was presented. Due to the fact that MSDM takes into account the complexity of socio-economic and biophysical systems, it was used in a multi-criteria analysis of activities in the field of energy efficiency and reduction of fossil fuel consumption when implementing integrated renewable energy sources during the modernization of a single-family residential buildings.

The case study presented in (Campisi et al. 2018) concerns the evaluation of the alternatives for heating systems in a residential building localized in Italy. MCDM analysis (with fourteen assessment criteria) considers the following alternatives: 1) Liquid Petroleum Gas, LPG heating, 2) oil boiler heating, 3) heating with pellets, 4) heating with the heat pump, HP 5) heating with the HP cooperates with typical the solar thermal energy system, or 6) with photovoltaic system. The most significant criteria turned out to be investment costs (importance factor is ' 5 '), then support for domestic hot water production (importance factor is ' 4 '), operating costs and cleaning (importance factor is ' 3 '). The 'working life' criterion, for which the importance factor was 
' 0 ', turned out to be insignificant. In the end, the most economical installation turned out to be the HP with the solar thermal energy system (total MCDM index was 24.57), followed by the HP without any supporting (22.03) and then the HP with photovoltaic cells (20.09). If the investor decides on the most advantageous alternative from szyk- from the point of view of the MCDM alalysis of the MCDM analysis view, the reduction of $\mathrm{CO}_{2}$ emission to the Earth's atmosphere will be approx. $73 \%$, and the payback time for investment expenditure will be approx. 4 years.

In addition to the LOCE typical for the energy sector, the Net Present Value NPV, the internal rate of return IRR and the Simple Pay-Back Time SPBT may be other relatively simple and willingly chosen statistical methods of making investment decisions.

The profitability of an on-grid PV installation for three buildings located in southern Finland has been discussed in (Simola et al. 2018). The energy demand for analysed cases, i.e. a grocery store, a dairy farm and a family house, is $89 \mathrm{kWp}, 28 \mathrm{kWp}$ and $5.2 \mathrm{kWp}$, respectively. The NPV and IRR indicators are used to assess the profitability of the investment. On their basis, it is found that:

- PV installation for a single-family house is not profitable; the solution could be an annual increase in electricity of $0.6 \%$ and higher tax credits for this purpose;

- PV installation for a store can be profitable with the annual decrease in energy prices by $3.6 \%$ and with subsidies at the level of $25 \%$;

- PV installation for a dairy farm can be profitable with a $3.3 \%$ annual decrease in energy prices while maintaining subsidies.

The price of PV installations for less than 10 $\mathrm{kWp}$ and the low price of electricity in Finland make small installations unprofitable. In addition, the high variability of insolation conditions in Finland is a significant problem, as the greatest demand occurs in winter, when the number of hours of sunshine and the intensity of solar radiation are lowest.

Generally, PV installations with a higher selfconsumption of electricity, such as a shop or a dairy, are considered profitable; they also receive higher subsidies from government programs for PV installations than those with a capacity below $10 \mathrm{kWp}$.
The installed capacity of grid-connected PV solar cells in Finland is steadily increasing, but still appears to be low compared to the potential of residential rooftops. Moreover, the low profitability of PV systems in Finland is largely due to sociotechnical, management, economic and policy barriers (Sami and Ahvenniemi 2019).

This work is mainly to show how diverse the level of insolation in European countries is and how it affects the possibilities of effective use of renewable energy from the sun (see the "Solar irradiation density in Europe" and "Global power density and photon current simulation for into module solar irradiation" sections) on the specific case. Nevertheless, the other technical and economic factors were also mentioned for future detailed analysis (see section 2.3).

This paper discusses an example of an already completed investment of the thermomodernization of an educational building, located in the geometric centre of Europe, near Bialystok, Poland, where the intensity of solar irradiation is not high compared to other European countries (Š́ri et al. 2007; No Author 2020a). The mean values of the total intensity of the solar radiation on the horizontal surface (ITH) obtained for this region were compared to the maximum and minimum ITH values for Malta and Finland and presented in the "Methods" section. The next part of this paper discusses detailed data of the energy audit of the building. The building was subjected to extensive thermomodernization improvements such as the installation of photovoltaic cells cooperating with a heat pump as an alternative energy source (basic parameters of the building and thermal upgrading range - see the "A boiler room supported by PV system - case study" section). The optimization of the PV installation size was carried out based on the following:

- reduction of $\mathrm{CO}_{2}$ emissions to $90 \%$ compared to the state before the modernization

- off-grid system operation.

Environmental analysis and results of the calculations of $\mathrm{CO}_{2}$ emissions for the current status and with alternative energy sources are delivered in the "Environmental analysis of the assumed thermal up-grading option" section.

The next subsection deals with economic evaluation and delivers simple and discounted economic efficiency indicators calculated for a sample investment, such as 
SPBT, NPV and IRR (see the "Economic evaluation" section). The last "Detailed conclusions" section compares, discusses and concludes obtained values. Moreover, future research direction and limitations of the case study were also considered.

\section{Methods}

Solar irradiation density in Europe

It turns out that, according to the calculations of Szymon Antonii Sobiekrajski of 1775, the geometric centre of Europe is located in north-eastern Poland, in Suchowola near Biaystok. According to statistical data originating from a weather station in this area, developed based on full 30-year measurement cycles used for energy balances of buildings, the sum of total intensity of solar irradiation incident on a horizontal plane amounts to $\mathrm{ITH}_{\mathrm{av} \text {,year }}=897.14 \mathrm{kWh} / \mathrm{m}^{2}$ (the monthly average is $\mathrm{ITH}_{\mathrm{av}, \text { month }}=74.76 \mathrm{kWh} / \mathrm{m} 2$ ) (No Author 2020a), while this value for Poland and Europe is estimated (based on interpolation and modelling of 580 meteorological measurements constituting a database for a period of $1981-1990)$ at $1012 \mathrm{kWh} / \mathrm{m}^{2}\left(\mathrm{ITH}_{\mathrm{av}, \text { month }}=84.33 \mathrm{kWh} /\right.$ $\mathrm{m} 2)$ and $1205 \mathrm{kWh} / \mathrm{m}^{2}\left(\mathrm{ITH}_{\mathrm{av}, \text { month }}=100.42 \mathrm{kWh} / \mathrm{m}^{2}\right)$, respectively (Hernandez-Moro and Martinez-Duart 2013; No Author 2020b). The highest and lowest values of total intensity $\mathrm{ITH}_{\mathrm{av}, \text { year }}$ are recorded in Malta and Finland and they amount to $1766 \mathrm{kWh} / \mathrm{m}^{2}$ and 841 $\mathrm{kWh} / \mathrm{m}^{2}$, respectively. The distribution of direct average annual solar irradiation in Poland and European countries is mapped and updated in the Solar GIS base in an ongoing manner (The World Bank 2019). The Solar GIS database has been validated at $200+$ locations globally. A long historical archive of solar irradiation data is available for any location between latitudes of $60 \mathrm{~N}$ and 45S.

Figure 1 presents a general map of the distribution of total annual average solar irradiation for Poland and for European countries.

Figure 2 presents the monthly distribution of total solar irradiation intensity for the geometric centre of Europe-a spot near Bialystok, which indicates that the monthly average solar irradiation intensity for the geometric centre of Europe is lower by approx. $26 \mathrm{kWh} /$ $\mathrm{m}^{2}(26 \%)$ than the European average $\left(100 \mathrm{kWh} / \mathrm{m}^{2}\right)$. It results in muchreduction in photovoltaic solar electricity potential for the purpose of its conversion and utilization, shown in Fig. 1b. The yearly sum of solar electricity generated by optimally-inclined $1 \mathrm{~kW}_{\text {peak }}$ system with a performance ratio of 0.75 for Poland, Malta and Finland are 675, 1,325 and $631 \mathrm{kWh} / \mathrm{kW}_{\text {peak }}$ respectively.

Additionally, Fig. 2 shows also a climograph representing European countries with extreme values of the dry-bulb temperature, MDBT (Mean Dry Bulb Temperature), which is compared to the ITH value for the geometric centre of Europe.

Figure 3 in turns presents average ITH values recorded by the Photovoltaic Geographical Information System (PVGIS) for European Communities between 2001-2019, which indicate that Poland is rated twentieth in terms of the conditions of insolation, and the ITH in here is lower by $16 \%$ and $43 \%$ than the European average and the maximum average for Malta, respectively, and higher by $17 \%$ than the minimum average recorded for Finland.

For the highest possible utilisation of the energy potential of PV panels, it is suggested to optimise their tilt angle, or additionally to commission a tracking system (Ngo et al. 2020; Whang et al. 2019); the 18-year average optimal angle of the position of photovoltaic panels for Poland amounts to approx. $36^{\circ}$, with $32^{\circ}$ for Malta and even $45^{\circ}$ for Finland (see Fig. 4).

Global power density and photon current simulation for into module solar irradiation

Making appropriate simulations are necessary to highlight the large differences in solar conditions in European countries with respect to each season. It is directly related to potential use of renewable solar energy resources (especially in the heating season).

The assessment of average solar conditions existing in Europe was performed using version 1.1.1 of the PV Lighthouse calculator (No Author 2020d).

Simulations were performed for the central part of Europe - an area near Bialystok (Poland), the capitals of Malta-Valletta and Finland-Helsinki, for which the respective values of total average intensity of solar irradiation on the horizontal plane were the highest and the lowest. Special attention should be paid to Finland, for which, due to locational aspects, the conditions of insolation were also estimated in the city of Rovaniemi, situated in the Arctic Circle. The input data and sample results of the performed simulations of global vs wavelength incident on the module are listed in Table 1 and in Figs. 5 and 6. The tilt angle 
Fig. 1 Map of total solar irradiation in (a) Poland (The World Bank 2019) and in (b) Europe with additional data of photovoltaic solar electricity potential (Jäger-Waldau et al. 2019; No Author 2020c)

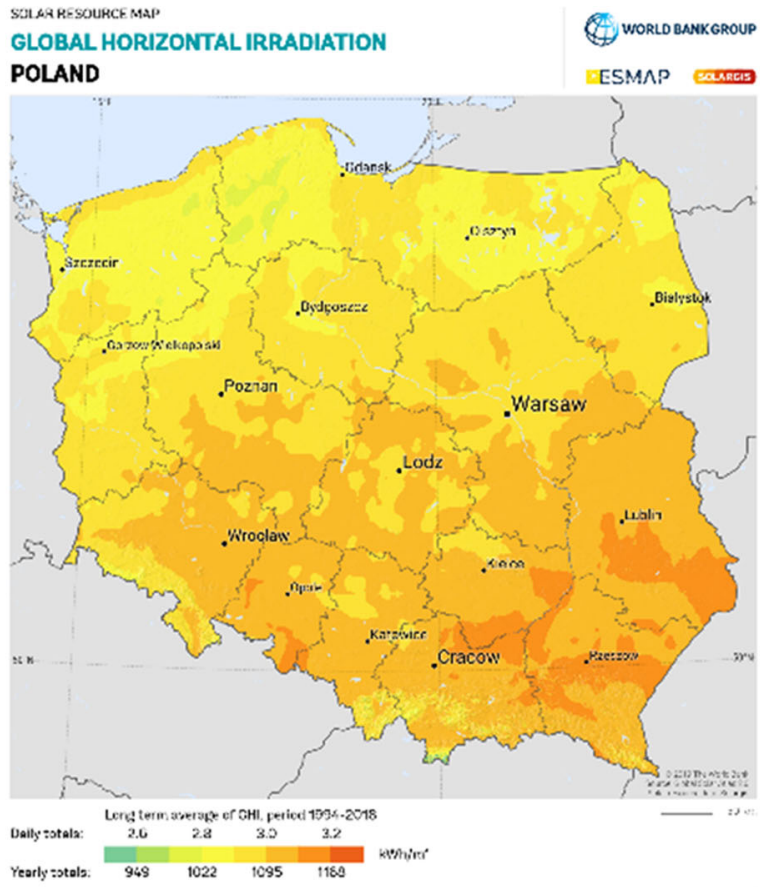

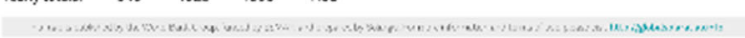

(a)

Photovoltaic Solar Electricity Potential in European Countries

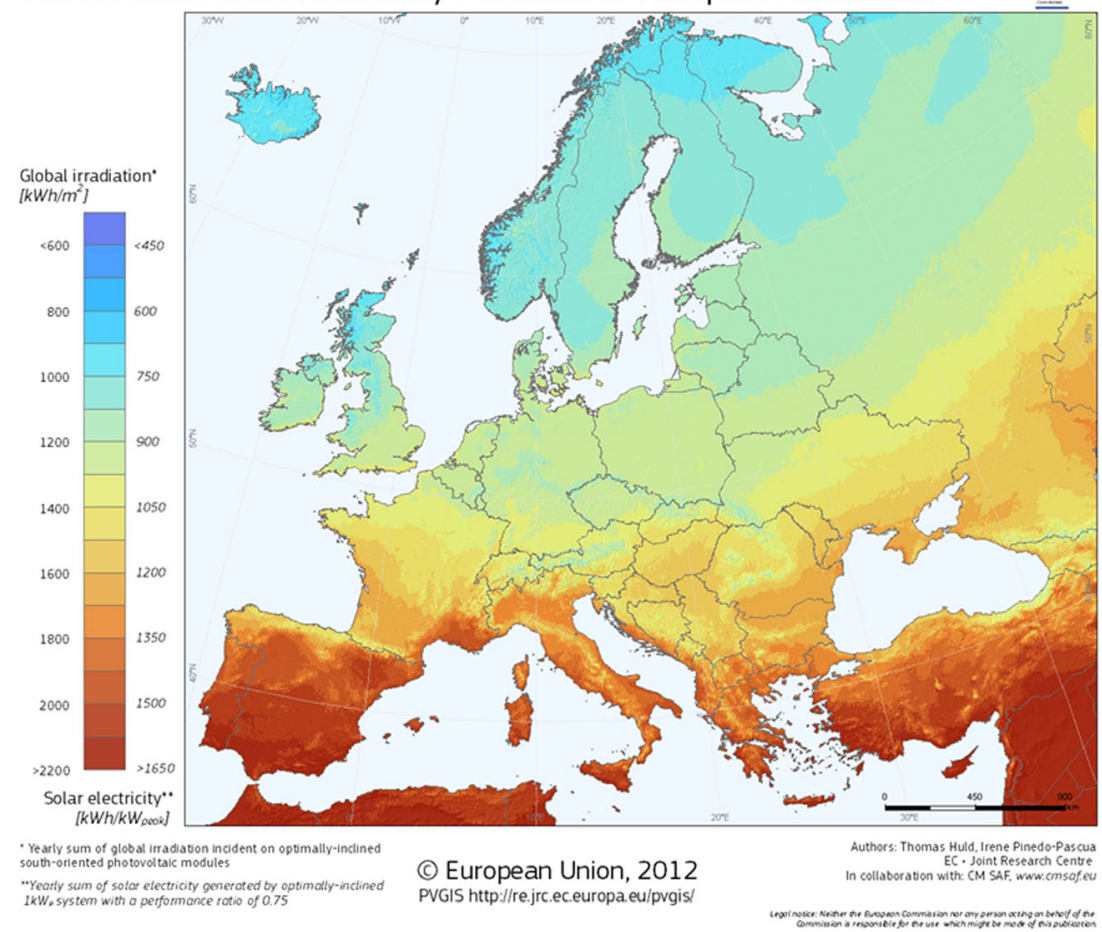

(b) 
Fig. 2 A climograph for selected European countries

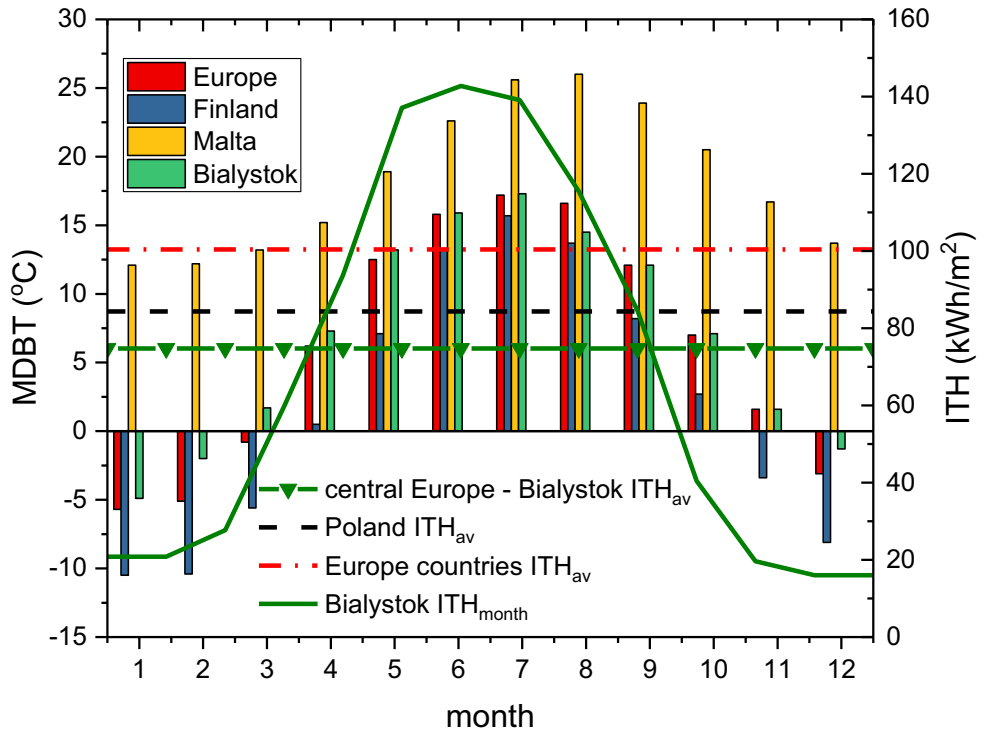

varying among countries results from the optimisation of the positioning of solar panels aimed at the utilisation of their maximum capacity (see Fig. 4).

Figures 5 and 6 present global power density and photon current in the central point of Europe in comparison to the results from Malta (Valletta) and Finland (Helsinki) for into module solar irradiation; the values are related to simulations of insolation as of 1 Jan and 15 Jul 2019.
As can be seen from Figs. 5 and 6, the middle of summer, which is considered to occur on the 15 th of July, does not exhibit high variances in insolation in each one of the analysed cases. The difference between the values of power density and photon current for Poland, Malta and Finland does not exceed 3.5\% for solar rays with an average optimal angle for a given country, amounting to 36,32 and $45^{\circ}$, respectively.

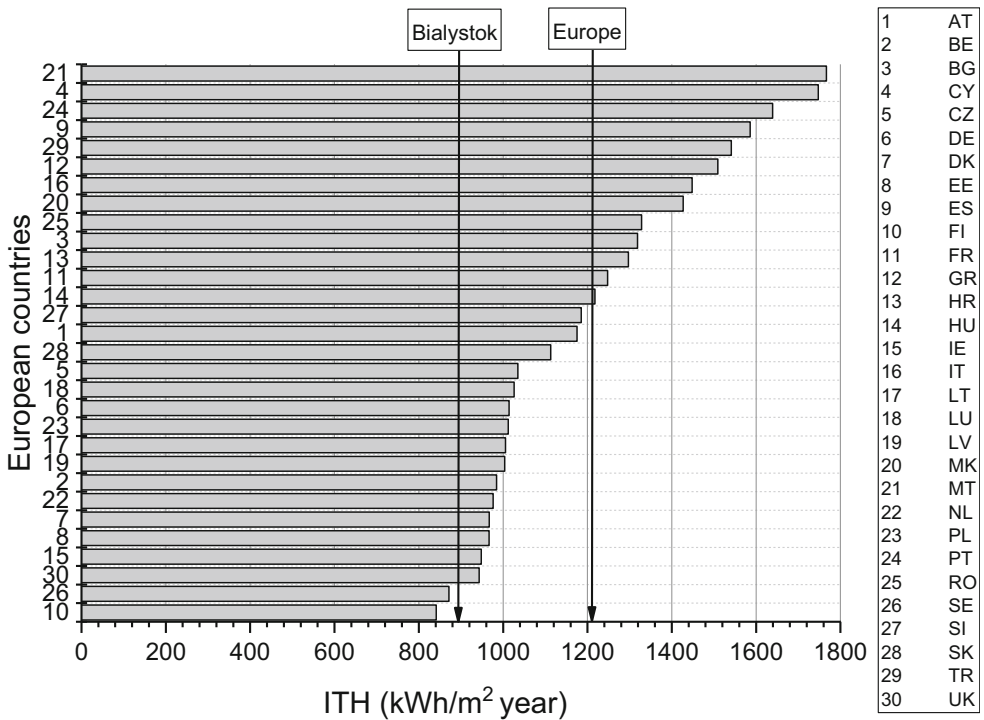

Fig. 3 Total average intensity of solar irradiation on the horizontal plane for European countries (Global yearly irradiation); 1-ATAustria, 2-BE- Belgium, 3-BG- Bulgaria, 4-CY- Cyprus, 5-CZCzech Republic, 6-DE- Germany, 7-DK- Denmark, 8-EE- Estonia, 9-ES- Spain, 10-FI- Finland, 11-FR- France, 12-GR- Greece, 13-HR-Croatia, 14-HU- Hungary, 15-IE- Ireland, 16-IT- Italy, 17-
LT- Lithuania, 18-LU- Luxembourg, 19-LV- Latvia, 20- MKRepublic of North Macedonia, 21-MT- Malta, 22-NL- Netherlands, 23-PL- Poland, 24-PT- Portugal, 25-RO- Romania, 26SE- Sweden, 27-SI- Slovenia, 28-SK- Slovakia, 29-TR- Turkey, 30- UK- United Kingdom 


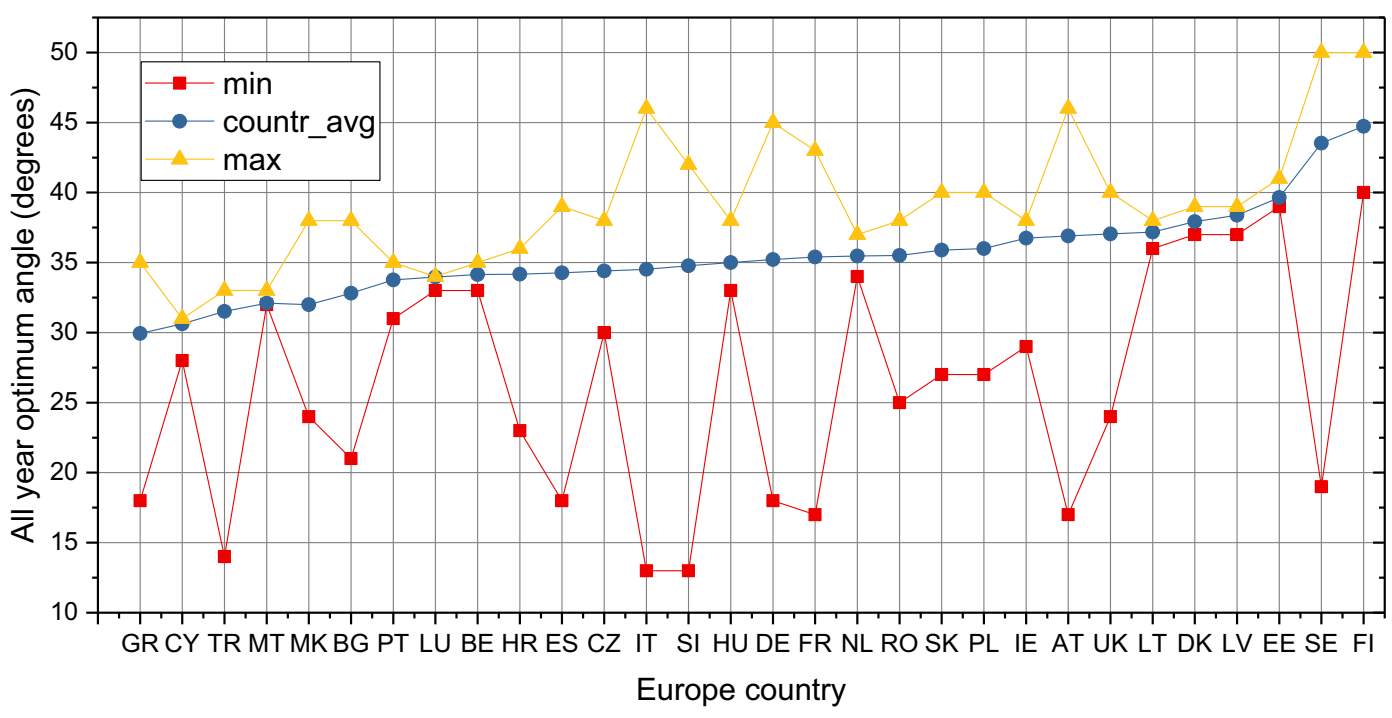

Fig. 4 The optimal tilt angle of photovoltaic panels (an average of 18 years) aimed at the utilisation of their maximum capacity

However, considering the data on insolation for January, in which the average respective numbers of sunshine hours recorded for Poland and Malta amount to 31 (No Author 2020e) and 169 (No Author 2020f) (meaning 5.5 times more solar energy in Malta in January and $33 \%$ more annually; see Fig. 7), the modelled values of power density and photon current exhibit considerable variability. Therefore, between the central point of Europe-Bialystok (Poland), the capitals of Malta-Valletta and Finland-Helsinki, the respective differences in power density amount to 54 and $33 \%$ (see Fig. 5); the photon current differences amount to 46 and $27 \%$ (see Fig. 6).

However, when the above values are related to the city of Rovaniemi (Finland), located in the Arctic Circle, the respective estimated differences in power density and the energy of photons will each time amount to approx. $\sim 98$ and $97 \%$ respectively.

The PV Lighthouse environment also enables determining an average number of sunlight hours in a day or year for any location. Figure 9 clearly shows the high diversity in the number of sunlight hours in the analysed countries of Europe.

\section{Results}

Above delivered analyses of the irradiation conditions in European countries of the medium, highest and lowest potential seems to be important from the design process of thermal up-grading.
A boiler room supported by PV system - case study

This chapter focuses on optimizing the size of PV installation for the sample educational building (area of $\mathrm{A}_{\mathrm{f}}$ $=1,324.29 \mathrm{~m}^{2}$ ) located in Bialystok, near the geometrical center of Europe. The building was comprehensively thermally upgraded. It resulted in heat demand decrease from 300 to $210 \mathrm{~kW}$ (see Table 2). Therefore, the scope of thermomodernization work was extensive. This study focused on one of the proposed improvements: the replacement of the gas heat source with an electric heat pump equipped with vertical heat exchangers and supported by a PV system. The technical aspect of selecting this type of applied heat source is not the subject of the analysis presented in this study. Moreover, the investorimposed guidelines, mainly relating to project financing, are operating a PV system in an off-grid system and reducing $\mathrm{CO}_{2}$ emissions to $90 \%$ of that before the modernization. Results of the calculations of $\mathrm{CO}_{2}$ emissions for the current status and with alternative energy sources are outlined and simple and discounted economic efficiency indicators calculated for a sample investment (such as the Simple Pay-Back Time SPBT, the net present value NPV and the internal rate of return IRR) are discussed.

Environmental analysis of the assumed thermal up-grading option

Table 2 presents basic and necessary input data for environmental analysis. Before thermal up-grading, in 
the current ' 0 ' status, the building is heated by means of a boiler fired with type $\mathrm{E}$ methane-rich natural gas; an electric brine-water heat pump (with vertical geothermal heat exchanger) supported by an off-grid PV system (battery capacity: $378720 \mathrm{Wh}$ ) has been proposed for use after thermal upgrading. Upon thermal upgrading, also encompassing the enhancement of heat insulation, the design heat load and usable energy decreased by $30 \%$; these figures are provided as supplementary data to show the general scale of modernisation works and are not significant from the point of view of the calculations below. Estimated length of the heating period for the region of Bialystok is 200 days so the PV system is designed for this period of time.

In Table 2, 'Annual consumption of electricity by the boiler assembly, PAK, kWh/annum' is so-called auxiliary energy used only for equipment such as circulation pumps and control units; 'yearly fuel consumption' refers to the fuel that the heating source uses; in ' 0 ' option it is natural gas, type $\mathrm{E}$ and in ' 1 ' option it is electric power.

Calculations of the annual amounts of carbon dioxide emitted into the atmosphere and its ecological effect are based on emission indicators listed in Table 3 (Institute

Table 1 General and atmospheric input and output data for simulations using the PV Lighthouse calculator

\begin{tabular}{|c|c|c|c|c|}
\hline \multirow{2}{*}{$\frac{\text { Country }}{\text { City }}$} & \multirow{2}{*}{$\frac{\text { Poland }}{\text { Bialystok }}$} & \multirow{2}{*}{$\frac{\text { Malta }}{\text { Valletta }}$} & \multicolumn{2}{|l|}{ Finland } \\
\hline & & & Helsinki & Rovaniemi \\
\hline Longitude & $23.1643300^{\circ}$ & $14.5147200^{\circ}$ & $24.9354500^{\circ}$ & $25.7166700^{\circ}$ \\
\hline Latitude & $53.1333300^{\circ}$ & $35.8997200^{\circ}$ & $60.1695200^{\circ}$ & $66.5000000^{\circ}$ \\
\hline Albedo & \multicolumn{4}{|l|}{0.3} \\
\hline Tilt angle & $36^{\circ}$ & $32^{\circ}$ & $45^{\circ}$ & \\
\hline Azimuth angle & \multicolumn{4}{|l|}{$180^{\circ}$} \\
\hline Earth-Sun factor & \multicolumn{4}{|l|}{0.967} \\
\hline Atmospheric pressure, mbar & \multicolumn{4}{|l|}{1013.25} \\
\hline Turbidity at 500, $\mathrm{nm}$ : & \multicolumn{4}{|l|}{0.084} \\
\hline Precipitable water vapour, $\mathrm{cm}$ & \multicolumn{4}{|l|}{1.4164} \\
\hline Ozone, atm-cm & \multicolumn{4}{|l|}{0.3438} \\
\hline Incident spectrum & \multicolumn{4}{|c|}{$\begin{array}{l}\text { AM0 [Gue95] - the Air Mass } 0 \text { spectrum, generated with SMARTS v } 2.9 .2 \text { (with the SMARTS/Gueymard } \\
\text { model chosen for the extraterrestrial spectrum) }\end{array}$} \\
\hline Transmission model & \multicolumn{4}{|c|}{ SPCTRAL2 [Bir86] (Bird and Riordan 1984) } \\
\hline \multicolumn{5}{|l|}{ Outputs } \\
\hline \multicolumn{5}{|l|}{ Insolation; solar position } \\
\hline Date and hour & \multicolumn{4}{|c|}{$15-07-2019 ; 12: 00$} \\
\hline Air mass & 1.18 & 1.03 & 1.28 & 1.42 \\
\hline Zenith angle, & $31.86^{\circ}$ & 14.73 & 38.95 & 45.27 \\
\hline Azimuth angle & $177.30^{\circ}$ & 174.38 & 177.73 & 177.99 \\
\hline Incident angle & $4.41^{\circ}$ & 18.40 & 6.24 & 1.45 \\
\hline \multicolumn{5}{|c|}{ Power density (into module location) $\left(\mathrm{W} / \mathrm{m}^{2}\right)$ : see Figure 5} \\
\hline \multicolumn{5}{|c|}{ Photon current (into module location) $\left(\mathrm{mA} / \mathrm{cm}^{2}\right)$ : see Figure 6} \\
\hline Date and hour & \multicolumn{4}{|c|}{$01-01-2019 ; 12: 00$} \\
\hline Air mass & 4.16 & 1.93 & 8.37 & 107.55 \\
\hline Zenith angle, & 76.13 & 58.90 & 83.17 & 89.50 \\
\hline Azimuth angle & 179.17 & 179.06 & 179.19 & 179.20 \\
\hline Incident angle & 40.14 & 26.90 & 38.17 & 44.50 \\
\hline
\end{tabular}




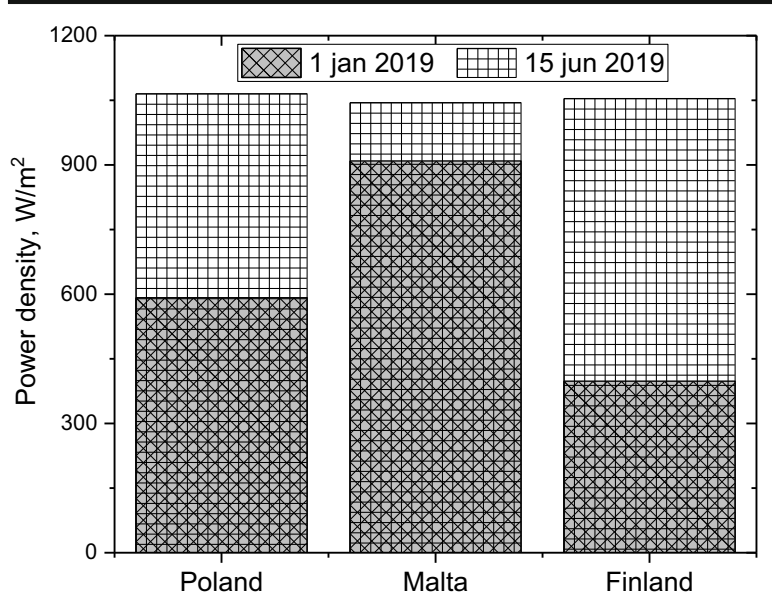

Fig. 5 Global power density in the central point of Europe (Poland) in comparison to Maltese and Finnish results for into module solar irradiation (integrated over a wavelength range of $280-4000 \mathrm{~nm}$ )

of Environmental Protection - National Research Institute 2020).

The total system efficiency is equal to $\eta_{\text {tot }}=3.6$ and derives from the following ratio: $\eta_{\text {tot }}=\eta_{\mathrm{g}} \cdot \eta_{\mathrm{e}} \cdot \eta_{\mathrm{d}} \cdot \eta_{\mathrm{s}}$; The individual components given here relate to the efficiency of: heat source (here a heat pump with $\eta_{\mathrm{g}}=$ COP $=3.8)$, regulation and use of heat in the heated space $\left(\eta_{e}=0.97\right)$, transmission $\left(\eta_{d}=0.98\right)$ and heat accumulation $\left(\eta_{\mathrm{s}}=1\right)$. Coefficient of Performance COP for a heat pump adopted above is typical for the production technology and market for these devices, not only in Poland (Campisi et al. 2018). The method of determining the total efficiency of the system, $\eta_{\text {tot }}$ is also common (Campisi et al. 2018).

Estimated yearly fuel consumption value, $\mathrm{P}_{\mathrm{elpc}}$ given in the Table 2 is calculated basis on the following dependence:

$$
\begin{aligned}
\mathrm{P}_{\mathrm{el} \mathrm{PC}}=\mathrm{FE} \cdot \mathrm{HP} \%= & 297.71 \frac{\mathrm{GJ}}{\mathrm{annum}} \cdot 277.8 \mathrm{kWh} \\
\cdot & 100 \% \\
= & 82,704 \frac{\mathrm{kWh}}{\mathrm{annum}}
\end{aligned}
$$

where, HP\% is the heat pump share in the energy balance.

What is more, calculated operating costs $c_{u}$ of the fuels are based on actual market prices and caloric values of the fuel supplier, $\mathrm{c}_{\mathrm{u}}=$ fuel unit cost/calorific values. Exemplary estimations are as follows:

$$
\begin{aligned}
& \text { for natural gas, type } \mathrm{E}, \mathrm{c}_{\mathrm{u}}=\frac{0.543 \frac{\mathrm{EUR}}{\mathrm{m}^{3}}}{0.0364 \frac{\mathrm{GJ}}{\mathrm{m}^{3}}}=14.86 \frac{\mathrm{EUR}}{\mathrm{GJ}} \\
& \text { for heat pump, } \mathrm{c}_{\mathrm{u}}=\frac{9.20 \frac{\mathrm{EUR}}{\mathrm{GJ}} \cdot 32 \%}{0.0036 \cdot 277.8 \frac{\mathrm{GJ}}{\mathrm{GJ}}}=2.94 \frac{\mathrm{EUR}}{\mathrm{GJ}}
\end{aligned}
$$

it is assumed that the operating cost of the heat pump is $32 \%$ of total electrical energy demand and that the rest originates from the PV installation.

The price of natural gas $0.543 \mathrm{EUR} / \mathrm{m}^{3}$ derives from (No Author 2021a) and may be a little bit differ from an average value for the country. It also depends on calorific value, an actual EURO exchange rate and on individual agreement between the supplier and the recipient.

An actual prices of electricity may be taken from (No Author 2021b) with the same limitations as above. The value of 9.20 EUR/GJ is calculated on the basis of the following assumptions and calculations: $\left(\mathrm{P}_{\mathrm{el}_{\mathrm{PC}}} \cdot 0.119 \frac{\mathrm{EUR}}{\mathrm{kWh}}\right) /\left(\mathrm{EU} \cdot 277.8 \frac{\mathrm{kWh}}{\mathrm{annum}}\right) \approx 9.20 \frac{\mathrm{EUR}}{\mathrm{GJ}}$.

In order to establish the direct ecological effect of the investment (Wciślik 2017; Moreno-Mondéjar and Cuerva 2020), the first step involves determining the emission of $\mathrm{CO}_{2}$ from a natural gas boiler station, for option ' 0 ' (formulas 3-5), the next one focusing on a boiler station based on a system of heat pumps (formulas 6-7); the combined results and the achieved reduction in $\mathrm{CO}_{2}$ are presented in Tables 4 and 5.

Annual emission of $\mathrm{CO}_{2}$ from a natural gas boiler:

$\mathrm{E}_{\mathrm{E}}^{\mathrm{CO}_{2}}=\mathrm{V}_{\mathrm{E}} \cdot \mathrm{WO}_{\mathrm{E}} \cdot \mathrm{WE}_{\mathrm{E}}$

Annual emission of $\mathrm{CO}_{2}$ from electrical energy for powering the boiler assembly:

$\mathrm{E}_{\mathrm{el}_{\mathrm{BA}}}^{\mathrm{CO}_{2}}=\mathrm{P}_{\mathrm{el}_{\mathrm{BA}}} \cdot \mathrm{WO}_{\mathrm{el}} \cdot \mathrm{WE}_{\mathrm{el}}$

Total annual emission of $\mathrm{CO}_{2}$ for the boiler station:

$\mathrm{E}_{\mathrm{E}_{\text {tot }}}^{\mathrm{CO}_{2}}=\mathrm{E}_{\mathrm{E}}^{\mathrm{CO}_{2}}+\mathrm{E}_{\mathrm{el}_{\mathrm{BA}}}^{\mathrm{CO}_{2}}$

Annual emission of $\mathrm{CO}_{2}$ from electrical energy for powering the heat pumps:

$\mathrm{E}_{\mathrm{el}}^{\mathrm{CO}_{2}}=\mathrm{E}_{\mathrm{el}} \mathrm{l}_{\mathrm{PC}}=\mathrm{P}_{\mathrm{el}_{\mathrm{pC}}} \cdot \mathrm{WO}_{\mathrm{el}} \cdot \mathrm{WE}_{\mathrm{el}}$

Combined annual emission of $\mathrm{CO}_{2}$ for a system based on heat pumps:

$\mathrm{E}_{\mathrm{el}_{\text {tot }}}^{\mathrm{CO}_{2}}=\mathrm{E}_{\mathrm{el} \text { pC }}^{\mathrm{CO}_{2}}+\mathrm{E}_{\mathrm{el}_{\mathrm{BA}}}^{\mathrm{CO}_{2}}$ 
Fig. 6 Global photon current in the central point of Europe in comparison to Maltese results for into module solar irradiation (integrated over a wavelength range of $280-4000 \mathrm{~nm}$ )

$$
\begin{gathered}
\mathrm{E}_{\mathrm{el}_{\mathrm{PC}}}^{\mathrm{CO}_{2}}=82,704 \mathrm{kWh} \cdot 3.6 \frac{\mathrm{MJ}}{\mathrm{kWh}} \cdot 93.63 \frac{\mathrm{kg}}{\mathrm{GJ}}=27,876.87 \frac{\mathrm{kg}}{\operatorname{annum}} \\
\mathrm{E}_{\mathrm{el}_{\mathrm{BA}}}^{\mathrm{CO}_{2}}=3,025 \mathrm{kWh} \cdot 3.6 \frac{\mathrm{MJ}}{\mathrm{kWh}} \cdot 93.63 \frac{\mathrm{kg}}{\mathrm{GJ}}=1,019.63 \frac{\mathrm{kg}}{\mathrm{annum}} \\
\mathrm{E}_{\mathrm{el}_{\mathrm{tot}}}^{\mathrm{CO}_{2}}=27,876.87+1,019.63=28,896.5 \frac{\mathrm{kg}}{\text { annum }}
\end{gathered}
$$

Resulting reduction in $\mathrm{CO}_{2}$ for a system based on heat pumps:

Fig. 7 The average number of sun hours for Poland, Malta and Finland

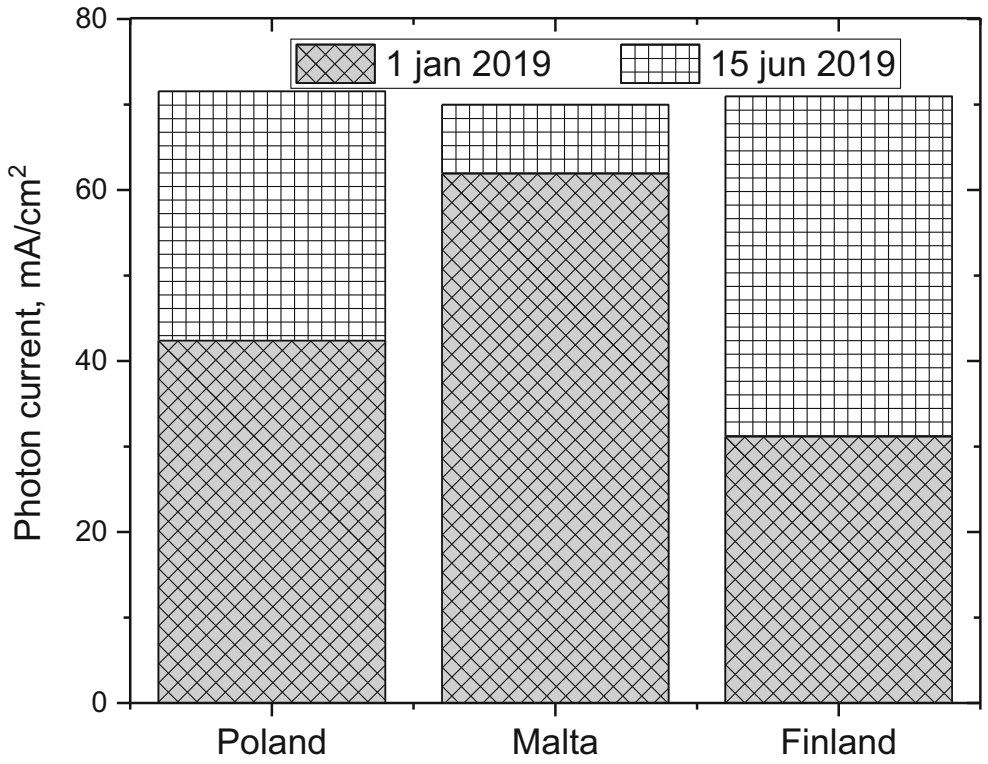

$\mathrm{E}_{\text {red. }}=1-\frac{\mathrm{E}_{\mathrm{el}_{\text {tot }}}^{\mathrm{CO}_{2}}}{\mathrm{E}_{\mathrm{E}_{\mathrm{tot}}}^{\mathrm{CO}_{2}}} \cdot 100, \%$

The next step involves determining the required minimum power of PV cells amounting to $\mathrm{P}_{\min }=36.43 \mathrm{~kW}$ (Eq. (9)) and their number $n_{P V}=182$, in order to achieve a minimum reduction in $\mathrm{CO}_{2}$ emission of $90 \%$ relative to the current status.

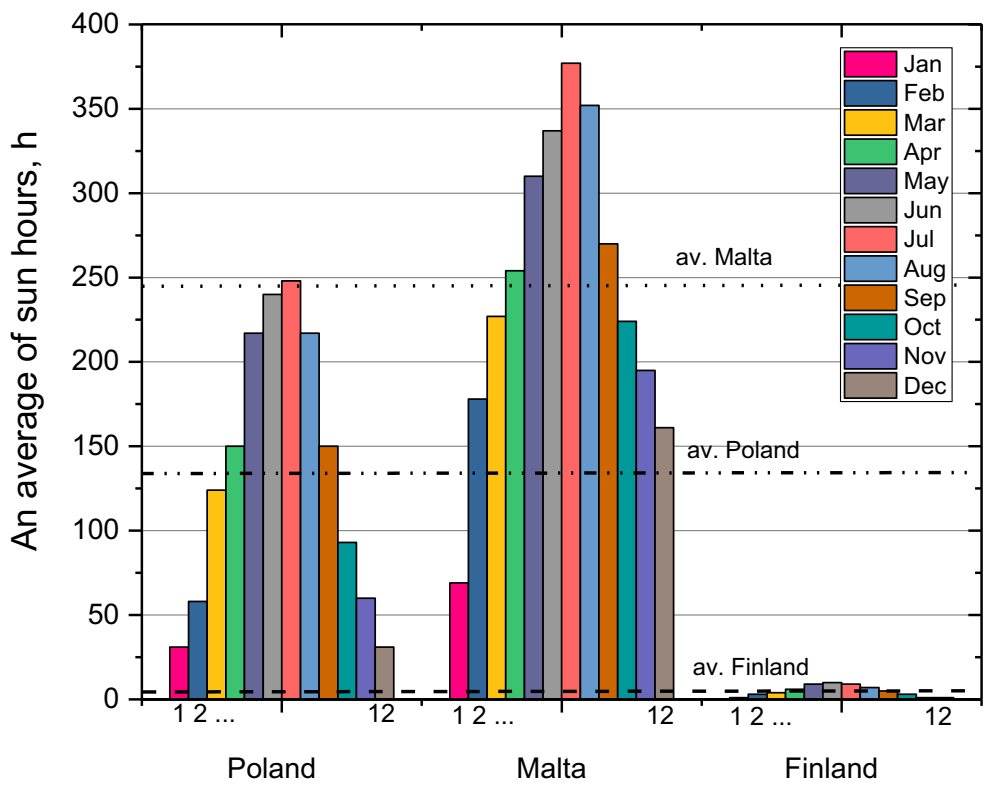


Table 2 A list of input data for determining the size of a PV installation

\begin{tabular}{|c|c|c|}
\hline Option & ' 0 ’ & ' 1 ' \\
\hline Fuel type & Natural gas, type E & Heat pump + PV cells \\
\hline Boiler station power, $\mathrm{kW}$ & 300 & 210 \\
\hline Usable energy for central heating and domestic hot water, UE, GJ/annum & $1,531.08$ & $1,071.74$ \\
\hline $\begin{array}{l}\text { Final energy demand for central heating and domestic hot water } F E=U E / \eta_{\text {tot }}{ }^{1}, G J / \\
\text { annum }\end{array}$ & $\begin{array}{l}1,531.08 / 0.74= \\
2,069.03\end{array}$ & $1,071.74 / 3.6=297.71$ \\
\hline Yearly fuel consumption & $V_{E}=51,037 \mathrm{~m}^{3} /$ annum $^{2}$ & $\begin{array}{r}\mathrm{P}_{\mathrm{el}}=82,704 \\
k W h / \text { annum }\end{array}$ \\
\hline Cost of $1 G \mathcal{J}^{3}, \mathrm{c}_{\mathrm{u}}, E U R / G J$ & 14.86 & 2.94 \\
\hline Annual consumption of electricity by the boiler assembly, $P_{A K}, k W h / a n n u m$ & 4320 & 3025 \\
\hline Length of the heating period & 200 days & \\
\hline
\end{tabular}

${ }^{1} \eta_{\text {tot }}$ is total system efficiency; ${ }^{2}$ according to the invoice of the fuel usage delivered by the investor; ${ }^{3}$ based on an actual market prices

$$
\mathrm{P}_{\min }=\frac{E_{\mathrm{el}_{\text {tot }}}^{\mathrm{CO}_{2}}-\left(\mathrm{E}_{\mathrm{E}_{\mathrm{tot}}}^{\mathrm{CO}_{2}} \cdot 10 \%\right) \cdot 1000}{\mathrm{WO}_{\mathrm{el}} \cdot \mathrm{WE}_{\mathrm{el}}}, \frac{\mathrm{kWh}}{\text { annum }}
$$

$$
\begin{aligned}
\mathrm{P}_{\min } & =\frac{28,896.5-(104,789.79 \cdot 10 \%) \cdot 1000}{3.6 \cdot 93.63} \\
& =54,640.37 \frac{\mathrm{kWh}}{\text { annum }}=\frac{54,640.37}{200 \mathrm{~d}} \\
& =273.20 \frac{\mathrm{kWh}}{\mathrm{d}}=\frac{273.20}{7.5 \mathrm{~h}}=36.43 \mathrm{~kW}
\end{aligned}
$$

The required number of PV panels:

$N P V=\frac{36.43}{0.2} \cong 182 \mathrm{pcs}$

In order to select the minimum number of PV cells, it was assumed that the estimated average daily time of harvesting energy by photovoltaic cells for the winter period is $7.5 \mathrm{~h}$ (see Fig. 9) (what is calculated in typical manner for such purposes and identically as in (Campisi et al. 2018)), the surface area of a single photovoltaic panel $-1.6 \mathrm{~m}^{2}$, and the recovery of electrical power from a single panel is $0.2 \mathrm{~kW}$.

Table 3 Calorific values (WO) and $\mathrm{CO}_{2}$ emission indicators (WE) in 2017 for reporting under the emissions trading system for 2020

\begin{tabular}{lll}
\hline Fuel type & $W O$ & $W E \mathrm{CO}_{2}$ \\
\hline Electrical energy & $3.6 \mathrm{MJ} / \mathrm{kWh}$ & $93.63 \mathrm{~kg} / \mathrm{GJ}$ \\
Methane-rich natural gas, type E & $36.54 \mathrm{MJ} / \mathrm{m}^{3}$ & $55.41 \mathrm{~kg} / \mathrm{GJ}$ \\
\hline
\end{tabular}

However, the power demand of the boiler room is $82.704 \mathrm{kWh} /$ annum. Assuming that the solar cells will cover $68 \%$ of this demand, we get the value of $56,238.72 \mathrm{kWh} /$ annum. In this case, the number of photovoltaic cells will increase to 187 .

\section{Economic evaluation}

For the proposed option of thermal upgrading analyses in the paper (exchange heat source for electric heat pump with vertical geometrical heat exchanger and supported by a PV system) the following simple and discounted indicators of economic efficiency are calculated:

SPBT - static method,

NPV_-dynamic method,

IRR - dynamic method.

In the analysed case, the Simple Pay-Back Time SPBT of expenses paid for an investment related to deep thermal upgrading, including primarily an exchange of the heat source with the necessary equipment $\left(\mathrm{N}_{1}=201,909\right.$ EUR), the purchase and assembly of photovoltaic panels $\left(\mathrm{N}_{2}=121,859\right.$ EUR) and gel batteries $\left(\mathrm{N}_{3}=154,525\right.$ EUR $)$ amounts to almost 25 years, which in the practice of investment economics is considered as an infeasible undertaking. Assumptions presented in Table 6 were made in order to estimate the static indicator of profitability, which is the SPBT.

What must be added, total costs of boiler room modernization $\left(\mathrm{N}_{1}\right)$ include the following: 
Table 4 Results of the calculations of $\mathrm{CO}_{2}$ emissions for the current status and with alternative energy sources

\begin{tabular}{|c|c|c|}
\hline \multirow[t]{2}{*}{$\mathrm{CO}_{2}$ emission } & \multicolumn{2}{|l|}{ Option } \\
\hline & $' 0 ’$ & $' 1$ ' \\
\hline \multicolumn{3}{|l|}{ kg/annum } \\
\hline $\mathrm{E}_{\mathrm{E} / \mathrm{PC}}^{\mathrm{CO}_{2}}$ & $103,333.66$ & $27,876.87$ \\
\hline $\mathrm{E}_{\mathrm{el}_{\mathrm{BA}}}^{\mathrm{CO}_{2}}$ & $1,456.13$ & $1,019.63$ \\
\hline $\mathrm{E}_{\mathrm{tot}}^{\mathrm{CO}_{2}}$ & $104,789.79$ & $28,896.5^{1}$ \\
\hline $\mathrm{E}_{\text {red. }}, \%$ & 72.42 & \\
\hline
\end{tabular}

${ }^{1} \mathrm{HP}$ without PV system

- 42 wells; the total length of the geothermal probes is $4.222 \mathrm{~m}$, and the unit drilling cost is $26.49 \mathrm{EUR} / \mathrm{m}$ ( $\sim$ EUR 111.841),

- Vitocal 300-G Pro BW2250 brine-water heat pump with $210 \mathrm{~kW}$ : EUR 72.407,

- the hydraulic equipment of the boiler room: EUR 17.661;

the given prices include VAT and result from the investor's cost estimate; given costs are typical for Polish market.

Moreover, assuming a discount rate of $\mathrm{R}=4 \%$, the indicator determined based on relationship (10) is NPV $<0$ and it amounts to $€-260,372.93$ which also negates the feasibility of the investment. The building service life was assumed as 15 years (a typical value for an investment of this type).
$N P V=\sum_{i=1}^{n} \frac{C F_{i}}{(1+R)^{i}}-N$

The investment turns out to be unquestionably profitable when the co-financing is $70 \%$. This level of cofinancing is possible to acquire via contests organized periodically with the participation of the European Union's capital, e.g. Norwegian Funds 2020. Therefore, when taking advantage of the funding, in this case SPBT $=7.32$ years, which is a value about the maximum threshold value for which the investment is considered profitable, meaning 7 years. Interestingly, already with $60 \%$ of funding, the dynamic indicator of economic efficiency, which is the NPV, deemed more credible than the SPBT, takes on values higher than ' 0 '. To be clear, the relationship between the NPV indicator and the discount rate was determined as well, as shown in Fig. 8 .

Table 5 Direct ecological effect of the investment ${ }^{1}$

\begin{tabular}{lllll}
\hline Emitted pollution1 & $\begin{array}{l}\text { Option } \\
\text { '0' }\end{array}$ & $\begin{array}{l}\text { Option } \\
\text { '1' }\end{array}$ & Ecological effect & Emission reduction \\
\hline & kg/annum & & & $\%$ \\
$\mathrm{SO}_{2}$ & 39.31 & 78.01 & -38.70 & -98.46 \\
$\mathrm{NO}_{\mathrm{X}}$ & 75.26 & 19.72 & 55.54 & 73.80 \\
$\mathrm{CO}$ & 21.35 & 5.92 & 15.44 & 72.30 \\
$\mathrm{CO}$ & $104,789.79$ & $3,807.322$ & $100,982.47$ & 96.37 \\
$\mathrm{PM}$ & 7.25 & 12.86 & -5.61 & -77.49 \\
$\mathrm{SOOT}$ & 0.01 & 0.02 & -0.01 & -98.46 \\
BENZOPYRENE & 0.00 & 0.00 & 0.00 & -98.46
\end{tabular}

\footnotetext{
${ }^{1}$ Except for $\mathrm{CO}_{2}$, the ratios of unit emissions are specified based on (Institute of Environmental Protection - National Research Institute 2020); negative values represent an increase in emissions, with positive ones for reduction

${ }^{2} \mathrm{HP}$ with PV system that reduces up to $90 \%$ of $\mathrm{CO}_{2} ;(27,876.87 \cdot 0.1)+1019.63=3,807.32 \mathrm{~kg} / \mathrm{annum}$
} 
Table 6 Assessment of the feasibility of modernisation of a heating installation

\begin{tabular}{|c|c|c|}
\hline \multirow[t]{2}{*}{ Feasibility assessment parameters } & \multicolumn{2}{|l|}{ Option } \\
\hline & ‘ 0 ’ & $' 1$ ' \\
\hline Fuel type & Natural gas, type $E$ & Heat pump + PV cells \\
\hline Fare for 1 GJ of heating, $c_{u} 1, E U R / G J$ & 14.86 & 2.94 \\
\hline Heating system efficiency, $\eta_{\text {tot }}$ & 0.662 & 3.6 \\
\hline Usable energy $U E^{2}$, GJ/annum & 1531.08 & 1071.74 \\
\hline Yearly cost savings $\Delta O^{3}, E U R / a$ & --- & $19,600.93$ \\
\hline Cost of modernisation - expenses, $\Sigma N$, EUR & --- & 478,293 \\
\hline$S P B T=\Sigma N / \triangle O$, year & & 24.4 \\
\hline
\end{tabular}

${ }^{1} \mathrm{c}_{\mathrm{u}}=\frac{0.543 \frac{\mathrm{EUR}}{\mathrm{m}^{3}}}{0.0365 \frac{\mathrm{G} . J}{\mathrm{~m}^{3}}}=14.86 \frac{\mathrm{EUR}}{\mathrm{GJ}} ; \mathrm{c}_{\mathrm{u}}=\frac{9.20 \frac{\mathrm{EUR}}{\mathrm{GJ}} \cdot 32 \%}{0.0036 \cdot 277.8 \mathrm{GJ}}=2.94 \frac{\mathrm{EUR}}{\mathrm{GJ}} ;$ on the basis of an actual Polish market prices and the fuels' caloric values; $\mathrm{N}_{1}+$ $\mathrm{N}_{2}+\mathrm{N}_{3}=201,909+121,859+154,525=478,293$ EUR; ${ }^{2}$ see Table $2 ;{ }^{3} \Delta O=\left(U E_{0_{0}^{\prime}} \cdot c_{u^{\prime} 0^{\prime}}\right)-\left(U E_{\prime_{1}^{\prime}} \cdot c_{u^{\prime} 1^{\prime}}\right)$ $=1531.08 \cdot 14.86-1071.74 \cdot 2.94=19,600.93 \frac{E U R}{a}$

Figure 8 indicates how the internal rate of return IRR changes depending on the level of funding. It has been shown that the IRR is higher than the discount rate $\mathrm{R}=$ $4 \%$ applicable in the calculation period with the cofinancing at the level of $60 \%$ and is equal to IRR = $5.9 \%$. Moreover, for $30 \%$ and lower co-founding, the investment seems to be completely unprofitable. IRR is calculated using Equation (11) and is the quantity at which NPV $=0$.

$N P V=0 \quad \sum_{i=1}^{n} \frac{C F_{i}}{(1+I R R)^{i}}=N$

Table 7 lists the basic indicators of economic efficiency of an investment implemented in an education center, near the geometrical center of Europe, involving the modernization of a gas boiler station and the assembly of a renewable heat source - a ground heat pump with a vertical heat exchanger (the technical aspect of the type of lower heat source is designers decision and is not the subject of the analysis presented in this study. The ground conditions as well as spatial and location possibilities of the investment were also part of the design of this project) supported by photovoltaic cells (the total costs include the purchase of a heat source, the drilling of boreholes, the assembly of PV cells along with gel batteries).

On-hand, and for good reason, performed calculations are involving the pay-back time for expenses paid for investments related to the system and use of renewable energy sources. These include e.g. photovoltaic cells, often pointing at very significant savings in operating costs, and reduced harmful substances emitted into Earth's atmosphere - especially carbon dioxide and particulate matter PM - compared to the conventional manner of producing this energy. However, these values should be related to the life cycle of a given installation, taking into account the energy, the costs and emissions associated with its components (Piasecka et al. 2020; de Almeida et al. 2020).

Moreover, in accordance with Eq. (1), Levelized Cost of Electricity, LCOE for exemplary installation is calculated for the following data set: investment expenditures, $\mathrm{I}_{\mathrm{t}}=\mathrm{N}_{2}+\mathrm{N}_{3}=276,384$ EUR, electrical energy generated, $\mathrm{E}_{\mathrm{t}}=56,238.72 \mathrm{kWh} /$ annum, discount rate $\mathrm{R}$ $=4 \% \div 10 \%$, the building service life (expected lifetime of the system), $\mathrm{n}=15 \div 25$ years. Total investment costs taken for consideration for LCOE calculations are only that involved with PV off-grid system and contains photovoltaic panels $\left(\mathrm{N}_{2}=121,859\right.$ EUR) and gel batteries $\left(\mathrm{N}_{3}=154,525 \mathrm{EUR}\right)$.

Based on the results of calculations of the costs of energy production from an off-grid photovoltaic installation presented in Fig. 9, it can be concluded that the greatest profitability of the investment is obtained when the LCOE cost is balanced with the average rates for electricity from the grid (in Poland it is $\sim 0.11 \mathrm{EUR} / \mathrm{kWh}$ (No Author 2021c)), i.e. only with a $70 \%$ subsidy, a discount rate of $4.6 \%$ and 20 years of the building's life. 
Fig. 8 NPV for an investment as a function of the discount rate, $\mathrm{R}$

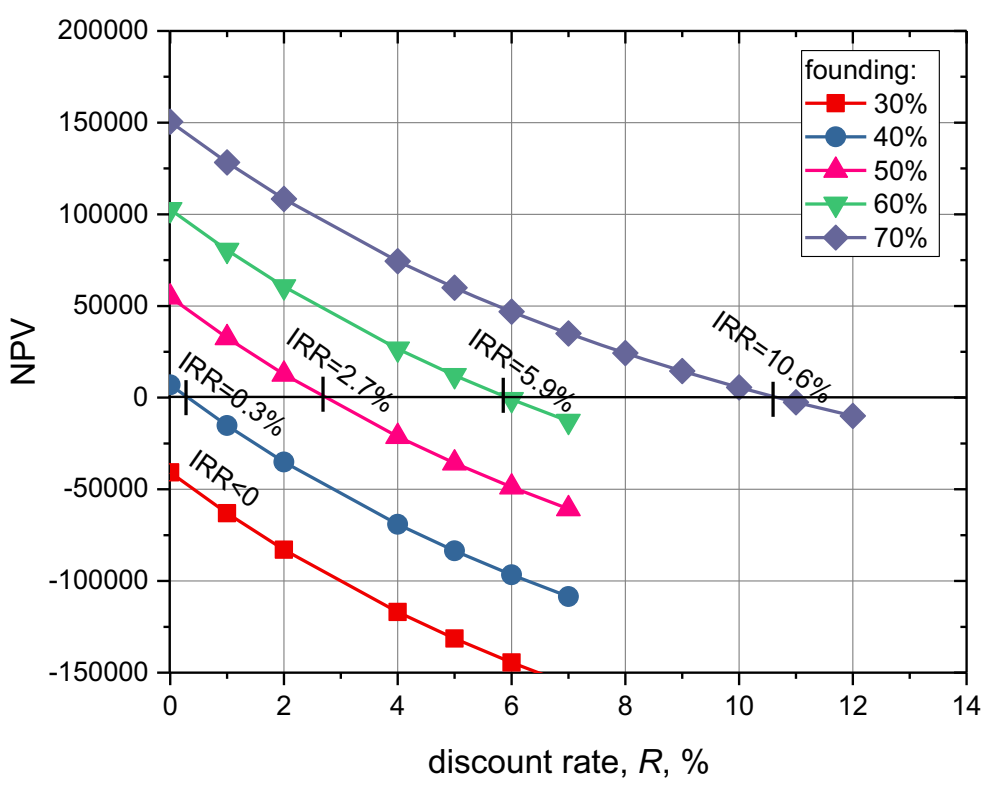

Generally, currently residential PV systems with storage (off-grid or hybrid) are still more than twice as expensive as PV on-grid systems (Jäger-Waldau 2019). As far as bigger installations (as in here $P>35$ $\mathrm{kWp}$ ) are concerned, in the literature there is no comprehensive studies to discuss with. But according to (Jäger-Waldau et al. 2019) and very meaningful and interesting study on the spatial distribution of the LCOE of rooftop grid-connected solar PV systems it is clearly shown that LCOE for Malta, Poland and Finland countries of the better, average and the worse solar irradiation in Europe-is $\sim 6,26$ and $20 \div 32$ EURcent/ $\mathrm{kWh}$ respectively. It confirms calculations delivered in Fig. 9a), where LCOE for off-grid PV installation without co-financing is presented. The costs of energy production is about two times higher than for gridconnected systems and are from $0.43 \mathrm{EUR} / \mathrm{kWh}$ to $0.59 \mathrm{EUR} / \mathrm{kWh}$ depending on the discount rate.
Power production estimation for grid-connected, tracking and off-grid systems

The simulation performed using the Photovoltaic Geographical Information System (PVGIS) application (No Author 2020c) allowed comparing the production of energy in a photovoltaic system for three cases:

1 on-grid,

2 in a tracking system,

3 off-grid

The calculations were performed for the same locations which are analyzed above: Bialystok - the geometrical centre of Europe, the capital of Malta-Valletta (with the best solar radiation conditions in EU, see Fig. 3), and the city of Helsinki (southern part of Finland) and Rovaniemi situated in the Arctic Circle, in

Table 7 Basic indicators of economic effectiveness for a sample investment

\begin{tabular}{lllllllll}
\hline Investment costs, EUR & 143,488 & 191,317 & 239,146 & 286,976 & 334,805 & 382,634 & 430,463 & 478,293 \\
\hline Funding, \% & 70 & 60 & 50 & 40 & 30 & 20 & 10 & 0 \\
Funding, EUR & 334.805 & 286.976 & 239.146 & 191.317 & 143.488 & 95.659 & 47.829 & 0 \\
SPBT, years & 7.32 & 9.76 & 12.20 & 14.64 & 17.08 & 19.52 & 21.96 & 24.40 \\
NPV & $74,431.97$ & $26,602.70$ & $-21,226.57$ & $-69,055.84$ & $-116,885.11$ & $-164,714.38$ & $-212,543.66$ & $-260,372.93$ \\
& $>0$ & & $<0$ & & & & & \\
IRR & $<0$ & & $>0$ & & & & & \\
& $10.6 \%$ & $5.9 \%$ & $2.7 \%$ & $0.3 \%$ & & & & \\
\hline
\end{tabular}


a)

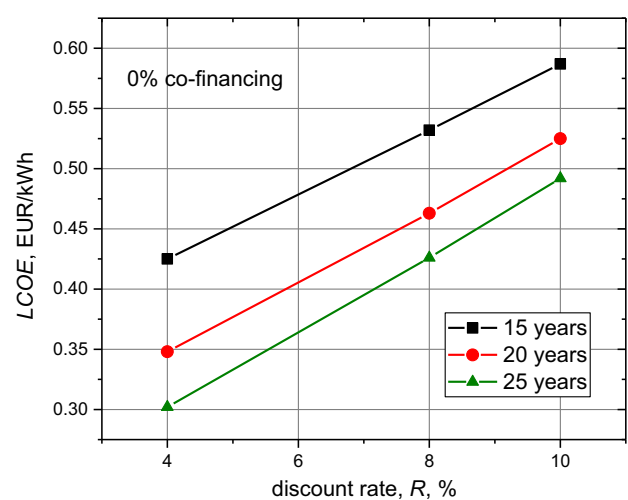

c)

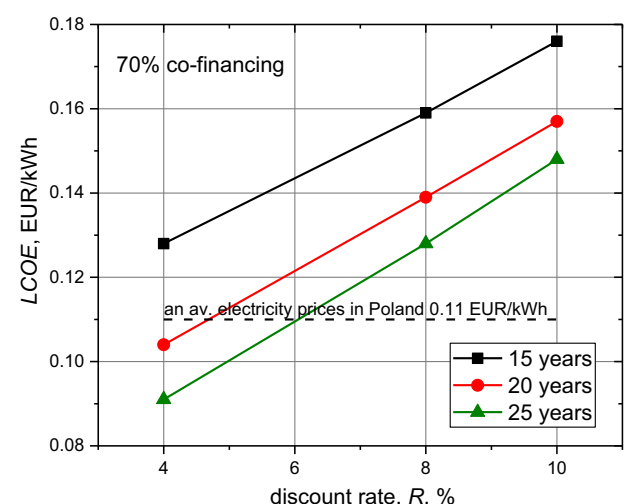

b)

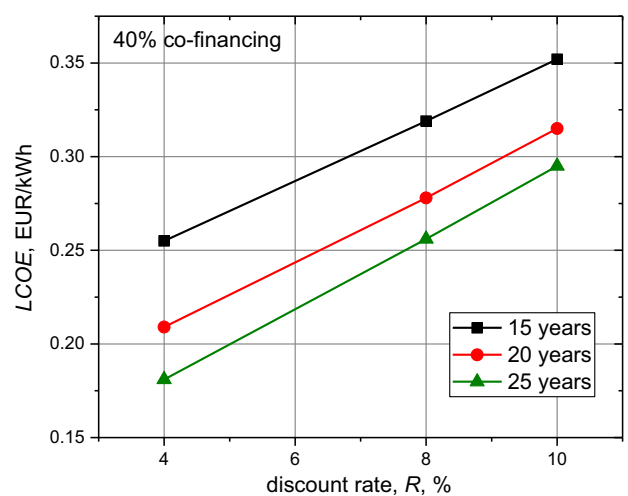

Fig. 9 Levelized Cost of Electricity, LCOE as a function of the discount rate, R for thermal up-grading based on the ground heat pump with vertical heat exchangers and PV off-grid system; a) $0 \%$ co-financing, b) $40 \%$ co-financing, c) $70 \%$ co-financing

Finland - country with the worst solar irradiation in EU. Due to diversity in solar radiation in Finland these two geographical localizations are analyzed. The results of the simulation are presented in Fig. 10 and exemplary simulation inputs are: PV installed: $36.43 \mathrm{kWp}$, system loss: $14 \%$, slope and azimuth: optimized for localization, the installation is integrated to the building, solar radiation database for Europe: PVGIS-ERA5, battery capacity: $32,787 \mathrm{Wh}$, Discharge cutoff limit is $40 \%$. Moreover, total yearly energy production from PV installation is performed in Fig. 11.

\section{Detailed conclusions}

The present study discusses the environmental and economic efficiency of a PV fitting supporting a modernised central heating system based on heat pumps with a vertical ground heat exchanger. Moreover, photovoltaic solar electricity potential for the purpose of its conversion and utilization among European countries was presented. The major conclusions of this study are as follows:

- the policy related to the requirements for obtaining energy from the Sun should at least be adjusted to conditions for each country;

this study compares the values of the total solar radiation density for a city of Bialystok, Poland in the central part of Europe $\left(897.14 \mathrm{kWh} / \mathrm{m}^{2} / \mathrm{yr}\right)$ to the maximum and minimum values recorded for Malta $\left(1766 \mathrm{kWh} / \mathrm{m}^{2} / \mathrm{yr}\right)$ and Finland $(841 \mathrm{kWh} /$ $\left.\mathrm{m}^{2} / \mathrm{yr}\right)$, respectively;

additionally, the monthly average solar irradiation intensity for the geometric centre of Europe is lower by approx. $26 \mathrm{kWh} / \mathrm{m}^{2} / \mathrm{mo}$ than the European average which is $100.42 \mathrm{kWh} / \mathrm{m}^{2} / \mathrm{mo}$ (see Fig. 2);

the potential of the utilisation of solar energy for the purpose of its conversion may reach even up to $49 \%$ what derives from Fig. 1; the yearly sum of solar electricity generated by optimally inclined $1 \mathrm{~kW}_{\text {peak }}$ system (for Poland, Malta and Finland it amounts to $36^{\circ}, 32^{\circ}$ and $45^{\circ}$ respectively) for 
Bialystok - European geographical central point

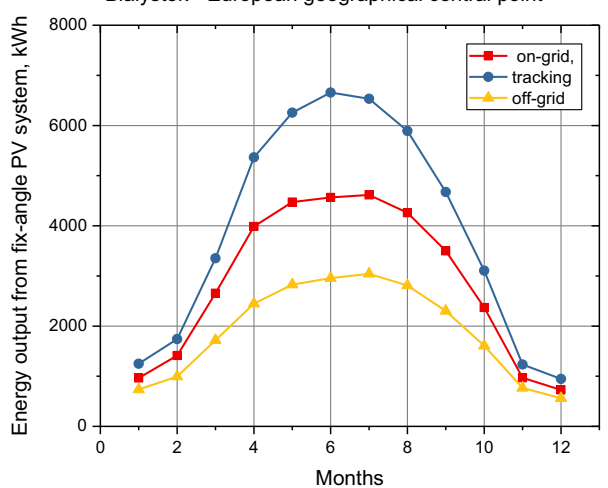

a)

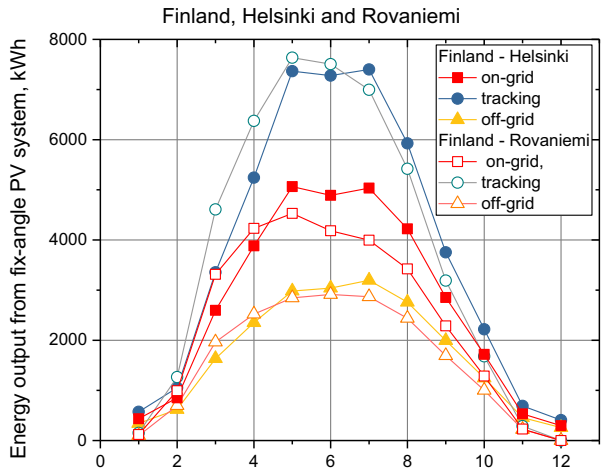

Malta, Valletta

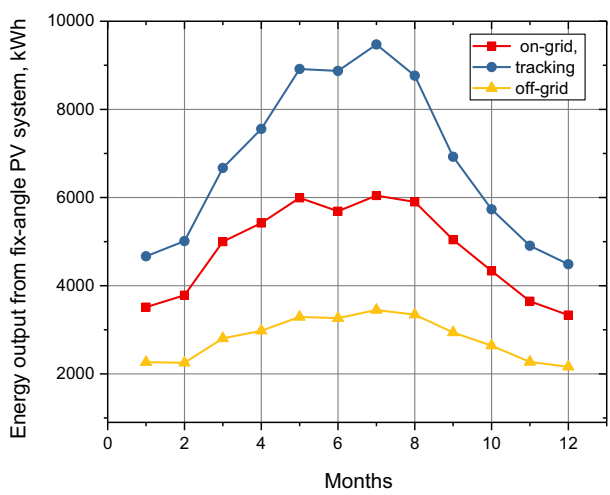

b)

c)

Fig. 10 The amount of electrical energy generated by a photovoltaic system for: a) the Bialystok location - the geometrical centre of Europe, b) Malta-Valletta, c) Finland-Helsinki and Rovaniemi locations

Fig. 11 The yearly energy production from the PV exemplary installation

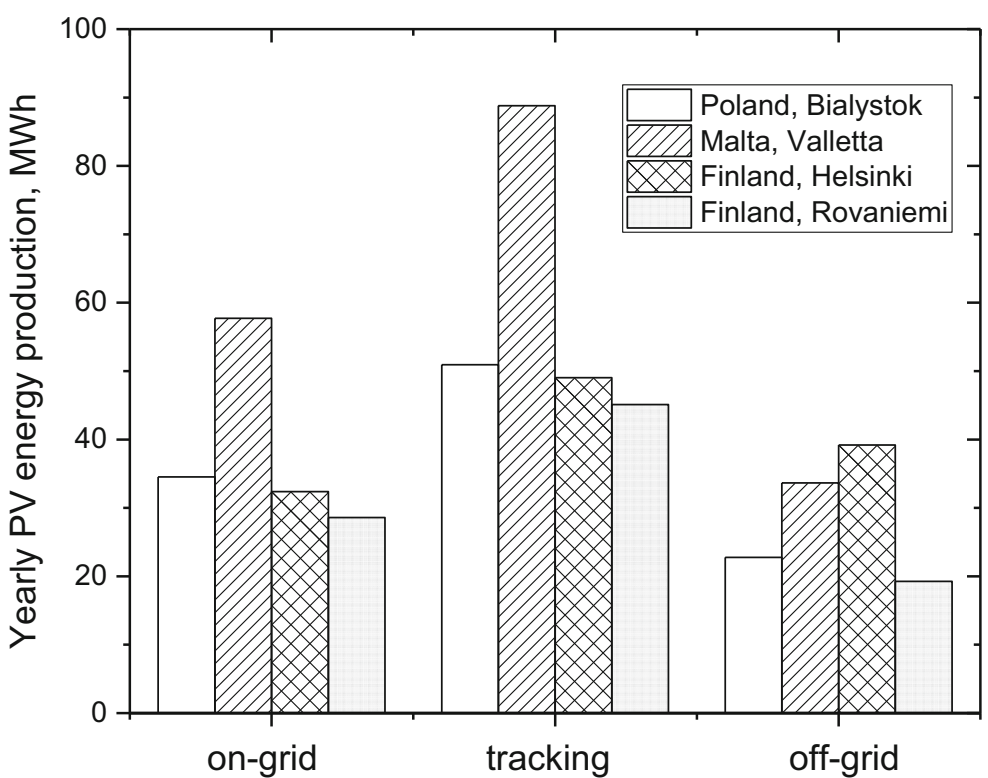


Poland, Malta and Finland is 675, 1,325 and 631 $\mathrm{kWh} / \mathrm{kW}_{\text {peak }}$ respectively; therefore, properly configurated system in Poland generates $51 \%$ of Malta system and 107\% of the system in Finland;

a detailed estimation of the effective solar energy usage for the above cases were obtained with PV Lighthouse calculator; the simulations confirmed a wide variety of global power density and photon current for into module solar irradiation, especially in the winter period;

between the central point of Europe-Bialystok (Poland), the capitals of Malta-Valletta and FinlandHelsinki, the respective differences in power density amount to 54 and $33 \%$; the photon current differences amount to 46 and 27\%; (see Figs. 5 and 6);

- the work deals also with environmental and simple economic analysis for specific case of the building localized near the geometrical Europe centre;

the building was thermally upgraded and the boiler room was modernized; the assumed works costs derive from the energy audit and concern a heat source replacement from gas boiler to an electric brine-water heat pump with vertical geothermal heat exchanger supported by an off-grid PV system;

in order to achieve a minimum reduction in $\mathrm{CO}_{2}$ emission of $90 \%$ (a level required to be granted funding) relative to the existing status it is necessary to install PV cells in a number of 182 , which generates high investment costs;

the Simple Pay-Back Time of expenses paid for the investment SPBT $=25$ years, which in the practice of investment economics is considered infeasible;

it is not until reaching $60 \%$ of funding that the dynamic indicator of economic efficiency NPV would take on values higher than ' 0 ';

an investment is entirely profitable with $70 \%$ of funding at which SPBT $\sim 7$ years although NPV $>0$; $\operatorname{IRR}=10.6 \%$ and is higher than the effective and adopted rate of return amounting to $4 \%$.

- the literature review shows that the cost of capital is the decisive factor for the profitability of the PV investments; the countries with good insolation conditions, but high capital costs (e.g. Bulgaria, Croatia) have a lower technical and economic solar electricity potential than countries with lower production costs, such as Germany or Belgium; the Levelized Cost of Electricity, LCOE of rooftop grid-connected PV systems for Malta, Poland and Finland is $\sim 6,26$ and $20 \div 32$ EURcent $/ \mathrm{kWh}$ respectively. But, the costs of energy production are about two times higher for off-grid systems and in Poland are from $0.43 \mathrm{EUR} / \mathrm{kWh}$ to 0.59 $\mathrm{EUR} / \mathrm{kWh}$ depending on the discount rate;

- simulations performed using the Photovoltaic Geographical Information System (PVGIS) shows diversity in energy production from the PV exemplary installations of $36.43 \mathrm{kWp}$ localized in Poland, Malta and Finland. PV grid connected system in Poland is $40 \%$ less efficient than in Malta and 12\% more than Finish average. In turn, off-grid installation in Poland is $32 \%$ less efficient than in Malta and $22 \%$ than Finish average. Tracking system is the best option and for each case is more of $32 \%$ effective in comparison with on-grid variant, but nowadays is seem to completely unprofitable.

Future investigations Due to the variation in the number of sunny hours and the intensity of solar radiation during the month, day and hour, it was decided for the Bialystok location to install an off-grid PV system with batteries with a capacity of $32,787 \mathrm{Wh}$. This allowed for the use of the obtained energy in transition periods, when the current production of electricity from PV cells is insufficient or even zero. The reports available in the literature most often refer to the annual power yield. In the case of locations with seasonally changing insolation conditions, an hourly and monthly simulations of the power efficiency should be presented, which is planned to be performed in further investigation. In periods off the heating season, the surplus energy is sold to the power grid with losses of $30 \%$; the accounting period falls at the end of the calendar year and any unused capacity is missed. Currently, the prices of the gel (and others) batteries used here are at a high level, but there is a downward trend. It is evident that installations of this type are becoming more and more popular. Their price is falling and the service life of the batteries available on the market is getting longer (now it is even about 12 years during buffer working). From the economic point of view, presented off-grid system is not profitable, however, it seemed to be the only one that met the criterion of co-financing investments from foreign funds at that time. The only criterion for receiving $88 \%$ funding was the reduction of $\mathrm{CO}_{2}$ emissions at the level of min. 90\%. Among the solutions analysed in the project and the energy audit, the installation of HP supported by PV operation seemed the most reasonable. 
In next term, it is planned to perform more detailed economic and environmental analysis and to compare the profitability of installations in the off-grid, on-grid and tracking system, taking into account the benefits, legal possibilities of connecting to the network and the economic situation of the European countries.

NomenclatureGreek Letters $\quad \lambda$, radiation wavelength Abbreviations (major) $C F$, cash flow; $C O$, carbon monoxide; $\mathrm{CO}_{2}$, carbon dioxide; $P E$, primary energy; $F E$, final energy demand; $U E$, usable energy demand; IRR, internal rate of return; ITH, the total intensity of the solar radiation incident on a horizontal surface; $\angle C O E$, levelized cost of electricity (or energy); $M C D M$, multi criteria decision making; $M D B P$, mean dry bulb temperature; $N O_{x}$, nitric oxide; $N P V$, net present value; $O Z E$, renewable energy sources; $P V$, photovoltaic; $P V G i S$, Photovoltaic Geographical Information System (PVGiS); $R$, discount rate; $S O_{x}$, sulfur oxide; $S P B T$, simple pay back time; $W A C C$, weighted average cost of capital symbols $E_{E \text { tot }}^{\mathrm{CO}_{2}}$, annual $\mathrm{CO}_{2}$ emissions for the boiler room; $E_{E}^{\mathrm{CO}_{2}}$, annual emissions from a natural gas boiler; $E_{\text {el } \mathrm{CA}}^{\mathrm{CO}_{2}}$, annual $\mathrm{CO}_{2}$ emissions from electricity to supply boiler fittings; $E_{e l ~ P C}^{C O_{2}}$, annual $\mathrm{CO}_{2}$ emissions from electricity for powering heat pumps; $E_{\text {el tot }}^{\mathrm{CO}_{2}}$, annual $\mathrm{CO}_{2}$ emissions for a heat pump system; $E_{\text {red }}$, reduction of $\mathrm{CO}_{2}$ emissions for a system based on heat pumps; $E_{t}$, electrical energy generated in the year; $F_{t}$, fuel expenditures in the year, $\mathrm{t} ; I_{t}$, investment expenditures in the year, $\mathrm{t} ; M_{\mathrm{t}}$, operations and maintenance expenditures in the year, $\mathrm{t} ; n$, expected lifetime of system or power station; $n_{P V}$, number of PV cells; $n_{t o t}$ total system efficiency; $P_{e l_{P C}}$, estimated annual fuel consumption for heat pump and PV cells; $P_{\min }$, required minimum power of $\mathrm{PV}$ cells; $R$, discount rate; $W E_{E}$, high-methane natural gas $\mathrm{CO}_{2}$ emission factor, type $\mathrm{E}$; $W E_{E b}$ electricity $\mathrm{CO}_{2}$ emission factor; $W O_{E}$, calorific value of high-methane natural gas, type $\mathrm{E} ; W O_{E L}$, calorific value of electricity; $V_{\mathrm{E}}$, estimated annual fuel consumption for type E natural gas; $\Delta O$, annual cost savings; $\Sigma N$, modernization cost - outlays

Funding 'Project financed under the programme of the Minister of Science and Higher Education called "Regional Initiative for Excellence" in the years $2019-2022$, project no. 025/RID/2018/ 19, amount of funding: 12,000,000 PLN'

\section{Declarations}

Conflict of interest The authors declare no competing interests.
Open Access This article is licensed under a Creative Commons Attribution 4.0 International License, which permits use, sharing, adaptation, distribution and reproduction in any medium or format, as long as you give appropriate credit to the original author(s) and the source, provide a link to the Creative Commons licence, and indicate if changes were made. The images or other third party material in this article are included in the article's Creative Commons licence, unless indicated otherwise in a credit line to the material. If material is not included in the article's Creative Commons licence and your intended use is not permitted by statutory regulation or exceeds the permitted use, you will need to obtain permission directly from the copyright holder. To view a copy of this licence, visit http://creativecommons.org/licenses/by/4.0/.

\section{References}

Berk A., Bernstein L., Robertson D. MODTRAN: A moderate resolution model for LOWTRAN. Tech. Rep. GL-TR-890122. Air Force Geophysics Lab. Hanscom AFB 1987 Massachusetts. USA.

Bird R., Riordan C., Simple Solar Spectral Model for Direct and Diffuse Irradiance on Horizontal and Tilted Planes at the Earth's Surface for Cloudless Atmospheres. Solar Energy Research Institute 1984

Bódis, K., Kougias, I., Jäger-Waldau, A., Taylor, N., \& Szabó, S. (2019). A high-resolution geospatial assessment of the rooftop solar photovoltaic potential in the European Union. Renewable and Sustainable Energy Reviews, 114, 109309. https://doi.org/10.1016/j.rser.2019.109309.

Campisi, D., Gitto, S., \& Morea, D. (2018). An Evaluation of Energy and Economic Efficiency in Residential Buildings Sector: A Multi-criteria Analisys on an Italian Case Study. International Journal of Energy Economics and Policy, 8(3), 185-196 ISSN: 2146-4553.

de Almeida, A., Moura, P., \& Quaresma, N. (2020). Energyefficient off-grid systems-review. Energy Efficiency, 13, 349-376. https://doi.org/10.1007/s12053-019-09813-y.

Directive 2006/32/EC of the European Parliament and of the Council of 5.04.2006 on energy end-use efficiency and energy services and repealing Council Directive 93/76/EEC.

Directive 2009/28 / EC of the European Parliament and of the Council of 23 April 2009 on the promotion of the use of energy from renewable sources. amending and subsequently repealing Directives 2001/77 / EC and 2003/30 / EC

Directive (EU) 2018/844 of the European Parliament and of the Council of 30.05. 2018 amending Directive 2010/31/EU on the energy performance of buildings and Directive 2012/27/ EU on energy efficiency (Text with EEA relevance).

Dzieża, J. (2017). Is LOCE a Good Measure of Investment Decision in Energy Industry? Finanse, Rynki Finansowe, Ubezpieczenia, 5(89/2), 273-284. https://doi.org/10.18276 /frfu.2017.89/2-20.

Evans, K. F., \& Stephens, G. L. (1991). A new polarized atmospheric radiative transfer model. J. Quant. Spectrosc. Ra.Transfer, 46, 413-423. https://doi.org/10.1016/00224073(91)90043-P. 
Gaglia, A. G., Lykoudis, S., Argiriou, A. A., Balaras, C. A., \& Dialynas, E. (2017). Energy efficiency of PV panels under real outdoor conditions - An experimental assessment in Athens. Greece. Renewable Energy, 101(C), 236-243.

Govaerts Y.: RTMOM V0B.10 Evaluation report. report EUM/ MET/DOC/06/0502. Eumetsat 2006.

Hernandez-Moro, J., \& Martinez-Duart, J. M. (2013). Analytical model for solar PV and CSP electricity costs: Present LCOE values and their future evolution. Renewable and Sustainable Energy Reviews, 20, 119-132. https://doi.org/10.1016/j. rser.2012.11.082.

Huijben, J. C. C. M., Podoynitsyna, K. S., van Rijn, M. L. B., \& Verbong, G. P. J. (2016). A review of governmental support instruments channeling PV market growth in the Flanders region of Belgium (2006-2013). Renewable and Sustainable Energy Reviews, 62, 1282-1290.

Institute of Environmental Protection - National Research Institute (KOBiZE). Calorific values (CO) and $\mathrm{CO} 2$ emission factors (EC) in 2017 to be reported under the Emission Trading Scheme for 2020. (Oryginal title: Instytut Ochrony Środowiska - Państwowy Instytut Badawczy (KOBiZE). Wartości opałowe (WO) i wskaźniki emisji $\mathrm{CO}_{2}$ (WE) w roku 2017 do raportowania w ramach Systemu Handlu Uprawnieniami do Emisji za rok 2020.)

Jäger-Waldau, A. PV Status Report 2019, EUR 29938 EN. Publications Office of the European Union, Luxembourg, 2019, ISBN 978-92-76-12608-9. DOI: https://doi. org/10.2760/326629,JRC118058.

Jäger-Waldau A., Bodis K., Kougias I., Szabo S. The new European renewable energy directive - opportunities and challenges for photovoltaics. European Commission. Joint Research Centre. Energy Efficiency and Renewables Unit. 21027. Italy 2019 Preprint 46th IEEE PVSC. Chicago. DOI: https://doi.org/10.1109/PVSC40753.2019.8980694

Kabir, E., Kumar, P., Kumar, S., Adelodun, A. A., \& Kim, K. (2018). Solar energy: potential and future prospects. Renewable and Sustainable Energy Reviews, 82, 894-900. https://doi.org/10.1016/j.rser.2017.09.094.

Key, J., \& Schweiger, A. (1998). Tools for atmospheric radiative transfer: Streamer and FluxNet. Computers and Geosciences, 24, 443-451. https://doi.org/10.1016/S0098-3004(97 )00130-1.

Lazard's levalized cost of Energy analysis - version 10.0, Lazard 2016

Leloux J., Narvarte L., Collares-Pereira M., Desportes A. Analysis of the state of the art of PV systems in Europe. PV Crops 2015 Photovoltaic Cost Reduction. Reliability. Operational performance. Prediction and Simulation, grant agreement no. 308468 .

Mehta, M. (2014). Estimation of aerosol optical depth over Dehradun (India) using simple model for atmospheric radiative transfer in multiple scattering approximation. The Int. Arch. Photogramm. Remote Sens. and Spatial Inf. Sci, XL-8, 271-276. https://doi.org/10.5194/isprsarchives-XL-8-2712014.

Moreno-Mondéjar, L., \& Cuerva, M. C. (2020). Fostering investment in resource efficiency actions: the case of European SMEs. Energy Efficiency, 13, 1329-1351. https://doi. org/10.1007/s12053-020-09888-y.

Muldashev, T. Z., Lyapustin, A. I., \& Sultangazin, U. M. (1999). Spherical harmonics method in the problem of radiative transfer in the atmosphere-surface system. Journal of Quantitative Spectroscopy and Radiative Transfer, 61, 393-404. https://doi.org/10.1016/S0022-4073(98)00025-9.

Ngo, X. C., Nguyen, T. H., Do, N. Y., Nguyen, D. M., Vo, D.-V. N., Lam, S. S., Heo, D., Shokouhimehr, M., Nguyen, V.-H., Varma, R. S., Kim, S. Y., \& Le, Q. V. (2020). GridConnected Photovoltaic Systems with Single-Axis Sun Tracker: Case Study for Central Vietnam. Energies, 13, 1457. https://doi.org/10.3390/en13061457.

No Author. www.mi.gov.pl [access: 01.10.2020a]

No Author https://ec.europa.eu/ [access: 01.10.2020b]

No Author https://re.jrc.ec.europa.eu/pvg_tools/en/tools.html [access: 01.10.2020c]

No Author https://www.pvlighthouse.com.au/calculator-map [access: 01.10.2020d]

No Author weather2travel.com. [access: 01.10.2020e]

No Author maltaweather.com [access: 01.10.2020f]

No Author https://ec.europa.eu/eurostat/statistics-explained/index. php/Natural_gas_price_statistics [access 23.02.2021a]

No Author https://www.statista.com/statistics/418110/electricityprices-for-households-in-poland/ [access 23.02.2021b]

No Author https://globenergia.pl/ [access 05.06.2021c]

Orzechowski T., Stokowiec K. Quasi-stationary phase change heat transfer on a fin. The European Physical Journal Web of Conferences 2016, 114 (02086). 1-5.

Ota, Y., Higurashi, A., Nakajima, T., \& Yokota, T. (2010). Matrix formulations of radiative transfer including the polarization effect in a coupled atmosphere-ocean system. Journal of Quantitative Spectroscopy and Radiative Transfer, 111, 878-894. https://doi.org/10.1016/j.jqsrt.2009.11.021.

Piasecka, I., Bałdowska-Witos, P., Piotrowska, K., \& Tomporowski, A. (2020). Eco-Energetical Life Cycle Assessment of Materials and Components of Photovoltaic Power Plant. Energies, 13, 1385. https://doi.org/10.3390 /en13061385.

Radl, J., Fleischhacker, A., Huglen, R. F., Lettner, G., \& Auer, H. (2020). Comparison of Profitability of PV Electricity Sharing in Renewable Energy Communities in Selected European Countries. Energies, 13, 5007. https://doi.org/10.3390 /en13195007.

Rasmussen, J. (2017). The additional benefits of energy efficiency investments - a systematic literature review and a framework for categorisation. Energy Efficiency, 10, 1401-1418. https://doi.org/10.1007/s12053-017-9528-1.

Renewable Energy Institute report „Photovoltaic Market in Poland" VIIIth edition. June 2020 (Original title: Instytut Energetyki Odnawialnej raport "Rynek Fotowoltaiki w Polsce“. VIII edycja czerwiec 2020)

Ricchiazzi, P., Yang, S., Gautier, C., \& Sowle, D. (1998). SBDART: A research and teaching software tool for planeparallel radiative transfer in the Earth's atmosphere. Bulletin of American Meteorological Society, 79, 2101-2114. .

Rozanov, A., Rozanov, V., Buchwitz, M., Kokhanovsky, A., \& Burrows, J. (2005). SCIATRAN 2.0 - A new radiative transfer model for geophysical applications in the 175-2400 $\mathrm{nm}$ spectral region. Advances in Space Research, 36, 10151019. https://doi.org/10.1016/j.asr.2005.03.012.

Ruggaber, A., Dlugi, R., \& Nakajima, T. (1994). Modelling radiation quantities and photolysis frequencies in the troposphere. Journal of Atmospheric Chemistry, 18, 171-210. https://doi.org/10.1007/BF00696813. 
Sami, K., \& Ahvenniemi, H. (2019). Pleasure is the profit - The adoption of solar PV systems by households in Finland. Renewable Energy, 133, 44-52. https://doi.org/10.1016/j. renene.2018.10.011.

Seidel, F., Kokhanowsky, A., \& Schaepman, M. (2010). Fast and simple model for atmospheric radiative transfer. Atmospheric Measurement Techniques, 3(4), 1129-1141. https://doi. org/10.5194/amt-3-1129-2010.

Simola, A., Kosonen, A., Ahonen, T., Ahola, J., Korhonen, M., \& Hannula, T. (2018). Optimal Dimensioning of a Solar PV Plant with Measured Electrical Load Curves in Finland. Solar Energy, 170, 113-123. https://doi.org/10.1016/j. solener.2018.05.058.

Stamnes, K., Tsay, S.-C., Wiscombe, W., \& Jayaweera, K. (1988). Numerically stable algorithm for discrete-ordinate-method radiative transfer in multiple scattering and emitting layered media. Applied Optics, 27, 2502-2509. https://doi. org/10.1364/AO.27.002502.

Šruri, M., Huld, T. A., Dunlop, E. D., \& Ossenbrink, H. A. (2007). Potential of solar electricity generation in the European Union member states and candidate countries. Solar Energy, 81, 1295-1305. https://doi.org/10.1016/j. solener.2006.12.007.

(C) 2019 The World Bank. Source: Global Solar Atlas 2.0. Solar resource data: Solargis.
Vartiainen E., Masson G., Breyer C. PV LCOE in Europe 201430, technical report. European PV Technology Platform 2015.

Vermote, E. F., Tanr'e, D., Deuz'e, J. L., Herman, M., \& Morcrette, J.-J. (1997). Second Simulation of the Satellite Signal in the Solar Spectrum. 6S: An Overview. IEEE T. Geosci. Remote, 35, 675-686.

Wciślik, S. (2017). Energy efficiency and economic analysis of the thermomodernization of forest lodges in the Świętokrzyski National Park. EPJ Web of Conferences, 143, 02144. https://doi.org/10.1051/epjconf/201714302144.

Whang, A. J.-W., Yang, T.-H., Deng, Z.-H., Chen, Y.-Y., Tseng, W.-C., \& Chou, C.-H. (2019). A Review of Daylighting System: For Prototype Systems Performance and Development. Energies, 12, 2863. https://doi.org/10.3390 /en12152863.

Zege, E. P., \& Chaikovskaya, L. (1996). New approach to the polarized radiative transfer problem. Journal of Quantitative Epectroscopy and Radiative Transfer, 55, 19-31. https://doi. org/10.1016/0022-4073(95)00144-1.

Publisher's note Springer Nature remains neutral with regard to jurisdictional claims in published maps and institutional affiliations. 